Supporting Information for

\title{
The Impact of Organometallic Intermediates on Copper-Catalyzed Atom Transfer Radical Polymerization
}

Marco Fantin, ${ }^{\dagger}+\dot{\dagger}$ Francesca Lorandi, ${ }^{\dagger}+{ }^{\dagger}$ Thomas G. Ribelli, ${ }^{\dagger}$ Grzegorz Szczepaniak, ${ }^{\dagger}$ Alan E. Enciso, ${ }^{\dagger} \S$ Christophe Fliedel, ${ }^{\|}$Lucas Thevenin," Abdirisak A. Isse, ${ }^{\perp}$ Rinaldo Poli, ${ }^{\| \# ~ K r z y s z t o f ~}$ Matyjaszewski ${ }^{* \dagger}$

${ }^{\dagger}$ Department of Chemistry, Carnegie Mellon University, 4400 Fifth Avenue, Pittsburgh, Pennsylvania 15213, United States

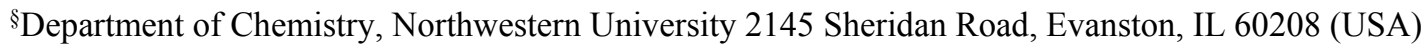

"CNRS, LCC (Laboratoire de Chimie de Coordination), Université de Toulouse, UPS, INPT, 205 Route de Narbonne, F-31077 Toulouse Cedex 4, France

${ }^{\perp}$ Department of Chemical Sciences, University of Padova, via Marzolo 1, 35131 Padova, Italy

\#Institut Universitaire de France, 1 Rue Descartes, 75231 Paris Cedex 05, France

\section{Table of contents}

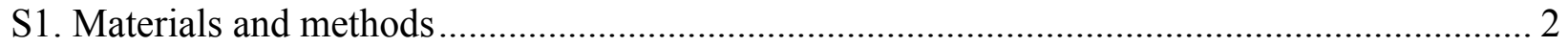

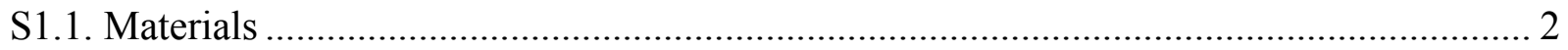

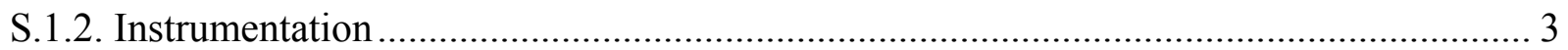

S.1.3. Procedures for electrochemical determination of $k_{\mathrm{a}, \mathrm{ATRP}}$ and electrochemical study of R-

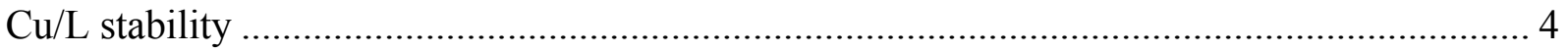

S1.4. Procedure for stopped-flow experiments ........................................................ 5

S1.5. Procedure for Vis-NIR termination experiments................................................. 5

S1.6. Procedure for the preparation of PMA-Br macroinitiator and characterization ............... 5

S1.7. Deconvolution of the Vis spectra ...................................................................... 7

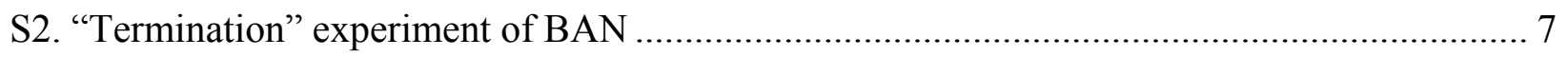

S3. Detailed description of the electrochemical simulation procedure................................... 8

S3.1. Electron transfer parameters, reactions 1) and 2) ............................................... 10

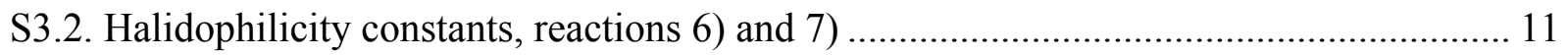




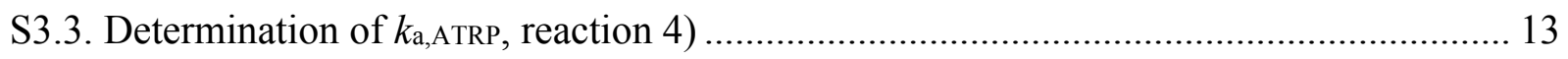

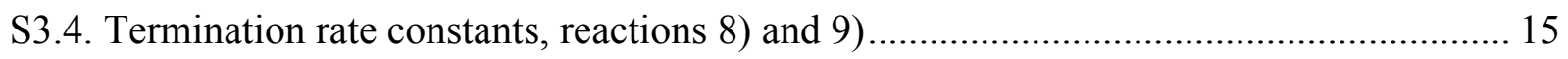

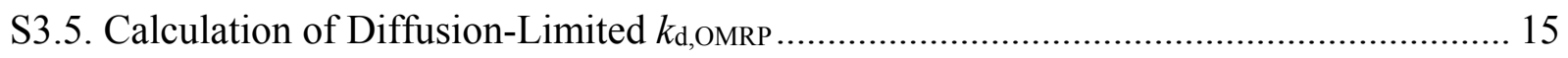

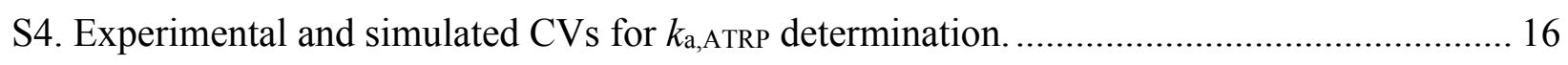

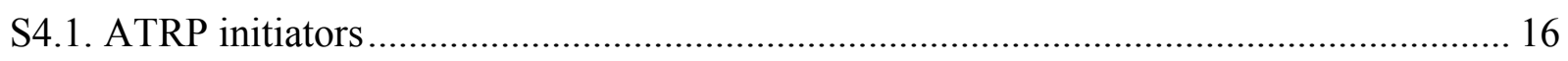

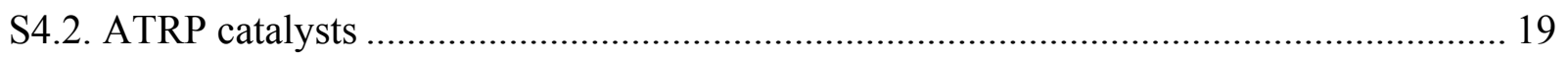

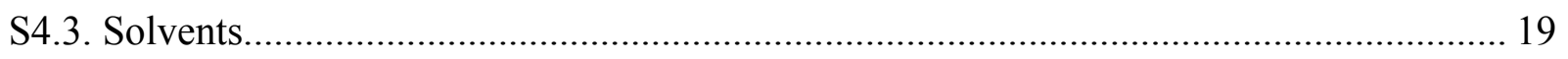

S5. Electrochemical analysis of the stability of R-Cu/L intermediates ........................................ 20

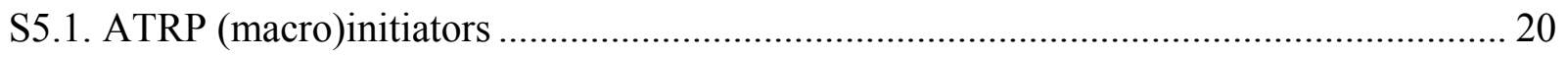

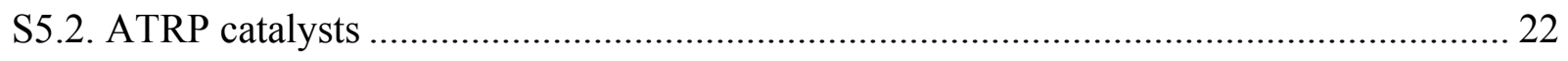

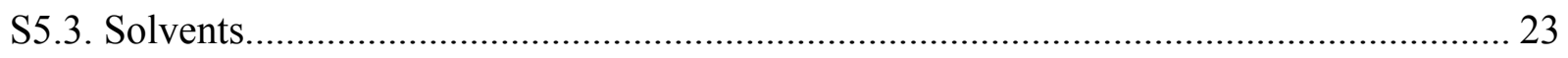

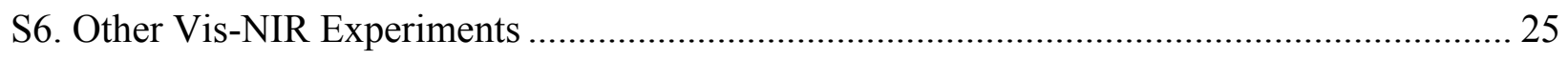

S7. "Termination” experiment for $\left[\mathrm{Cu}^{\mathrm{I}}(\mathrm{TPMA})\right]^{+}$and EBA in DMF ………………….............. 26

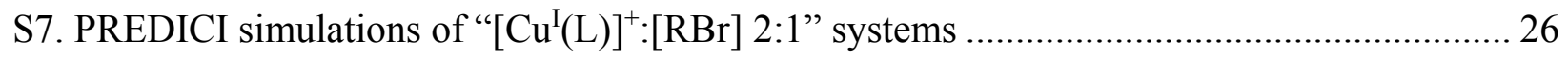

S8. PREDICI simulations under polymerization conditions …………………………............... 33

\section{S1. Materials and methods}

\section{S1.1. Materials}

Anhydrous N,N-dimethylformamide (DMF, Sigma-Aldrich, 99.8\%), anhydrous dimethyl sulfoxide (DMSO, Sigma-Aldrich, 99.9\%), copper(II) bromide ( $\mathrm{Cu}^{\mathrm{II}} \mathrm{Br}_{2}$, Sigma Aldrich, 99.999\% trace metal basis), tris(2-pyridylmethyl)amine (TPMA, AmBeed or Koei Chemical Co. Ltd, 98\%), ethyl $\alpha$-bromoacetate (EBA, Sigma-Aldrich, 98\%), methyl 2-bromopropionate (MBP, SigmaAldrich, 98\%), ethyl $\alpha$-bromoisobutyrate (EBiB, Sigma-Aldrich, 98\%), bromoacetonitrile (BAN, Sigma-Aldrich, 97\%), 2-bromopropionitrile (BPN, Sigma-Aldrich, 97\%), benzyl bromide (BnB, Sigma-Aldrich, 98\%), 1-phenylethyl bromide (PEB, Sigma-Aldrich, 98\%) were used as received. 
Anhydrous acetonitrile $\left(\mathrm{CH}_{3} \mathrm{CN}\right.$, Sigma-Aldrich, 99.8\%) was distilled over $\mathrm{CaH}_{2}$ under a nitrogen atmosphere and stored in a sealed flask.

Copper(II) trifluoromethanesulfonate $\left(\mathrm{Cu}^{\mathrm{II}}(\mathrm{OTf})_{2}\right.$, Sigma-Aldrich, 98\%) was dried under vacuum at $T \approx 80{ }^{\circ} \mathrm{C}$ for several hours prior to use. Copper(I) bromide $\left(\mathrm{Cu}^{\mathrm{I}} \mathrm{Br}\right.$, Sigma-Aldrich, 98\%) was purified by stirring in excess glacial acetic acid, followed by filtration and rinsing with ethanol and diethyl ether, then dried overnight in a vacuum oven at $70{ }^{\circ} \mathrm{C}$. A stock solution of copper(I) triflate $\left(\mathrm{Cu}^{\mathrm{I}} \mathrm{OTf}\right)$ in $\mathrm{CH}_{3} \mathrm{CN}$ was prepared by a comproportionation reaction between $\mathrm{Cu}^{\mathrm{II}}(\mathrm{OTf})_{2}$ and $\mathrm{a} \mathrm{Cu}(0)$ wire $($ dia. $=1 \mathrm{~mm}$, Sigma-Aldrich, $\geq 99.9 \%)$. The wire was washed in a solution of $\mathrm{HCl} / \mathrm{CH}_{3} \mathrm{OH} 1 / 3$. The comproportionation reaction was let to proceed for $24 \mathrm{~h}$ in a nitrogen-purged Schlenk flask, then the solution was standardized by spectrophotometric analysis to determine the $\mathrm{Cu}(\mathrm{I})$ concentration, using 2,9-dimethyl-1,10-phenanthroline as a specific ligand in a 2-fold excess with respect to the metal $\left(\varepsilon=8458 \mathrm{M}^{-1} \mathrm{~cm}^{-1}\right){ }^{1}$

Tetraethylammonium tetrafluoroborate $\left(\mathrm{Et}_{4} \mathrm{NBF}_{4}\right.$, Alfa Aesar, 99\%), used as a supporting electrolyte and tetraethylammonium bromide (Et $4 \mathrm{NBr}$, Sigma-Aldrich, 99\%) were recrystallized from ethanol and acetone, respectively. The salts were dried in a vacuum oven at $70{ }^{\circ} \mathrm{C}$ for $48 \mathrm{~h}$.

\section{S.1.2. Instrumentation}

Cyclic voltammetry (CV) was conducted on an Autolab PGSTAT100N (Metrohm), in a 6neck electrochemical cell with a three-electrode setup. The working electrode was a glassy carbon (GC) disk (Metrohm, $3 \mathrm{~mm}$ diameter); the GC surface was cleaned before each experiment, by polishing with a $0.25 \mu \mathrm{m}$ diamond paste, followed by ultrasonically rinsing in ethanol for 5 minutes. The counter electrode was a Pt ring, whereas the reference electrode was an home-made $\mathrm{Ag}|\mathrm{AgI}|(0.1 \mathrm{M} n$-Bu4NI in DMF) electrode in organic solvents, and a saturated calomel electrode (SCE) in water. Ferrocene was added at the end of each experiment as internal standard: all potentials were referred to SCE by using the following literature values for the standard reduction potential of the ferrocenium/ferrocene redox couple $\left(\mathrm{Fc}^{+} \mid \mathrm{Fc}\right): 0.390 \mathrm{~V}$ vs. $\mathrm{SCE}$ in $\mathrm{CH}_{3} \mathrm{CN}, 0.476$ $\mathrm{V} v s . \mathrm{SCE}$ in DMF, $0.449 \mathrm{~V}$ vs. SCE in DMSO. ${ }^{2}$

Spectrophotometric titrations and Vis-NIR termination experiments were conducted on a Agilent 8453 spectrophotometer in a $1 \mathrm{~cm}$ quartz cuvette. 
Molecular weight $\left(M_{\mathrm{n}}\right)$ and dispersity $(\nexists)$ of the PMA-Br macroinitiator were determined by gel permeation chromatography (GPC), equipped with Polymer Standards Services (PSS) columns (guard, $10^{5}, 10^{3}$, and $10^{2} \AA$ ) and a differential refractive index detector (Waters, 2410), with tetrahydrofuran (THF) as eluent at a flow rate of $1.00 \mathrm{~mL} / \mathrm{min}\left(T=35^{\circ} \mathrm{C}\right)$. GPC traces were processed by WinGPC 8.0 software (PSS) using a calibration based on linear polystyrene (PS).

Nuclear magnetic resonance (NMR) spectroscopy was used to measure monomer conversion during the synthesis of the macroinitiator and to characterize the purified macroinitiator. NMR spectroscopy was conducted on a Bruker Avance III spectrometer operating at $500 \mathrm{MHz}$ for ${ }^{1} \mathrm{H}$, in $\mathrm{CDCl}_{3}$ as solvent.

Simulation software: electrochemical simulations were performed using DigiElch Professional 8 (Gamry Instruments); simulations of polymerizations and termination experiments were conducted on PREDICI (CiT - Computing in Technology, v6.3.2). Model systems adopted in all different simulations and parameters' values are listed in detail in Section S3 (electrochemical simulations) and Section S7 and S8 (PREDICI simulations). Fitting of experimental data from Vis-NIR spectra in PREDICI were also conducted by using the model systems described in Section S7.

\section{S.1.3. Procedures for electrochemical determination of $k_{\mathrm{a}, \mathrm{ATRP}}$ and electrochemical study of $\mathrm{R}-\mathrm{Cu} / \mathrm{L}$ stability}

Prior to use, the electrochemical cell was cleaned with acetone and dried in an oven at $\sim 100$ ${ }^{\circ} \mathrm{C}$. Then, the three electrodes were put into the cell and the remaining necks were closed with PTFE caps. The supporting electrolyte, $\mathrm{Et}_{4} \mathrm{NBF}_{4}(0.325 \mathrm{~g}, 1.5 \mathrm{mmol})$, a stirring bar and $15 \mathrm{~mL}$ of anhydrous solvent were added to the cell under nitrogen flow. In the experiments for $k_{\mathrm{a}, \mathrm{ATRP}}$ determination, TEMPO $(0.117 \mathrm{~g}, 0.75 \mathrm{mmol})$ was also added into the cell. After degassing the solution for about 30 minutes, a first series of CVs was recorded with changing the scan rate $(0.05$, $\left.0.075,0.1,0.2,0.5,0.75 \mathrm{~V} \mathrm{~s}^{-1}\right)$ and it was subsequently used for the background subtraction. Then, typically $\mathrm{Cu}^{\mathrm{II}} \mathrm{Br}_{2}(0.0034 \mathrm{~g}, 0.015 \mathrm{mmol})$ and the ligand ([ligand $\left.] /[\mathrm{Cu}]=1.1\right)$ were added to the solution. After degassing for a few minutes, another series of CVs was recorded at the same scan rates and keeping the potential range constant. The same steps were repeated after each injection of the $\mathrm{RBr}$ initiator. 


\section{S1.4. Procedure for stopped-flow experiments}

The procedure is exemplified for the $\left[\mathrm{Cu}^{\mathrm{I}}(\mathrm{TPMA})\right]^{+}+\mathrm{BAN}$ experiment. A few milliliters of a degassed $\mathrm{Cu}^{\mathrm{I}}(\mathrm{OTf})$ solution $\left(2.4 \times 10^{-3} \mathrm{M}\right)$ were loaded into a nitrogen-purged $10 \mathrm{~mL}$ air-tight syringe. A few milliliters of a degassed solution of BAN $\left(1.2 \times 10^{-3} \mathrm{M}\right)$ and TPMA $\left(3.0 \times 10^{-3} \mathrm{M}\right)$ were loaded into a second $10 \mathrm{~mL}$ air-tight syringe. The syringes were connected to the stoppedflow instrument and the first few hundred microliters were discarded. Then, stopped-flow experiments were conducted at different time-scales, recording a full Vis spectra every $\sim 0.01 \mathrm{~s}$. The light path was $1 \mathrm{~cm}$.

\section{S1.5. Procedure for Vis-NIR termination experiments}

The procedure is exemplified for the $\left[\mathrm{Cu}^{\mathrm{I}}(\mathrm{TPMA})\right]^{+}+\mathrm{BAN}$ experiment. Prior to use, a Schlenk flask was rinsed with acetone and dried in an oven at $\sim 100{ }^{\circ} \mathrm{C}$. Then, in a typical termination experiment, the flask was purged with nitrogen and filled with a stirring bar, $4 \mathrm{~mL}$ of anhydrous solvent, BAN (1.1 $\mu \mathrm{L}, 0.016 \mathrm{mmol})$, and TPMA (0.0095 g, $0.033 \mathrm{mmol})$. A Vis-NIR spectrum $(400 \mathrm{~nm}-1100 \mathrm{~nm})$ of the solution was recorded as a baseline. Then the flask was subjected to three freeze-pump-thaw cycles and then purged with nitrogen. $\mathrm{Cu}^{\mathrm{I}}(\mathrm{OTf})([\mathrm{Cu}] /[\mathrm{BAN}]$ $=2 / 1$ ) was added to the flask at room temperature by withdrawing it from a stock solution under inert atmosphere. Vis-NIR spectra were immediately recorded and the solution was stirred between each spectrum.

\section{S1.6. Procedure for the preparation of PMA-Br macroinitiator and characterization}

The PMA-Br macroinitiator was prepared by $\mathrm{Ag}^{0}$ ATRP, according to a previously reported procedure. ${ }^{3}$ A mixture of $\mathrm{EBiB}(0.78 \mathrm{~g}, 4 \mathrm{mmol}), \mathrm{Cu}^{\mathrm{II}} \mathrm{Br}_{2}(10 \mathrm{mg}, 0.044 \mathrm{mmol})$, TPMA (13 mg, $0.048 \mathrm{mmol}$ ), $20 \mathrm{~mL}$ of MA (19 g, $0.222 \mathrm{~mol})$ and $20 \mathrm{~mL}$ of dimethylformamide (DMF) were added to a Schlenk flask and nitrogen-purged for about 30 minutes. This degassed solution was charged into another nitrogen-purged Schlenk flask containing $5 \mathrm{~cm}$ of a fresh $\mathrm{Ag}^{0}$ wire (dia $=2$ $\mathrm{mm}$ ) and a stir bar. The flask was sealed and placed in an oil bath at $50^{\circ} \mathrm{C}$. The polymerization 
was stopped after $1.5 \mathrm{~h}$ by opening the flask to the air. A monomer conversion of $68 \%$ was measured by ${ }^{1} \mathrm{H}$ NMR. The residual monomer was removed using a rotary evaporator. The polymer was precipitated in a mixture of $\mathrm{H}_{2} \mathrm{O} / \mathrm{MeOH}=9 / 1$ and was then centrifuged for 20 minutes. The polymer was collected and dried overnight in a vacuum oven to yield pure PMA-Br macroinitiator. A stock solution of PMA-Br in DMF was then prepared for the CVs experiments.

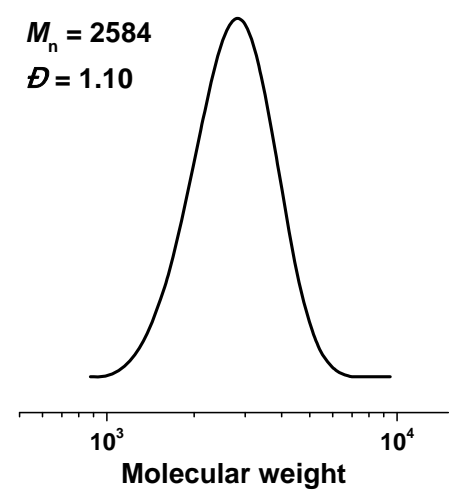

Figure S1. GPC trace of purified PMA-Br.

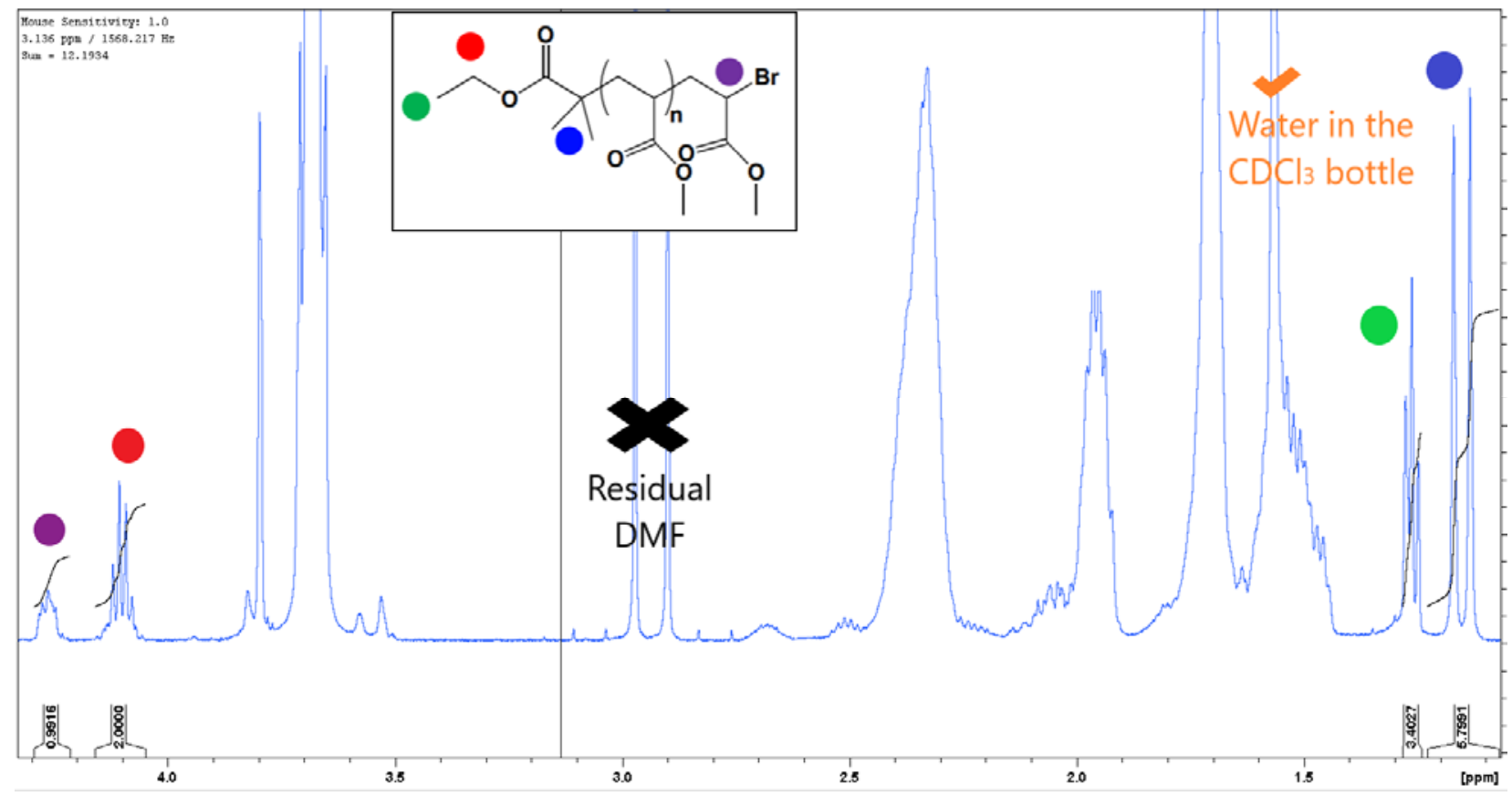

Figure S2. ${ }^{1} \mathrm{H}$ NMR of $\mathrm{PMA}-\mathrm{Br}$ in $\mathrm{CDCl}_{3}$ after purification and peak assignment. 


\section{S1.7. Deconvolution of the Vis spectra}

Deconvolution of the Vis spectra was conducted by using the reported spectra from Zerk and Bernhardt. ${ }^{4}$ At $600 \mathrm{~nm}\left[\mathrm{Cu}^{\mathrm{II}}\left(\mathrm{CH}_{2} \mathrm{CN}\right)(\mathrm{TPMA})\right]^{+}$has $\varepsilon=160 \mathrm{~L} \cdot \mathrm{mol}^{-1} \cdot \mathrm{cm}^{-1}$ in $\mathrm{CH}_{3} \mathrm{CN}$, while $\left[\mathrm{Cu}^{\mathrm{II}} \mathrm{Br}(\mathrm{TPMA})\right]^{+}$does not absorb. Therefore, the absorbance at $600 \mathrm{~nm}$ was used to obtain the concentration of $\left[\mathrm{Cu}^{\mathrm{II}}\left(\mathrm{CH}_{2} \mathrm{CN}\right) \text { (TPMA) }\right]^{+}$. At $725 \mathrm{~nm}$, $\left[\mathrm{Cu}^{\mathrm{II}}\left(\mathrm{CH}_{2} \mathrm{CN}\right)(\mathrm{TPMA})\right]$ has $\varepsilon=200$ $\mathrm{L} \cdot \mathrm{mol}^{-1} \cdot \mathrm{cm}^{-1}$, while $\left[\mathrm{Cu}{ }^{\mathrm{II}} \mathrm{Br}(\mathrm{TPMA})\right]^{+}$has $\varepsilon=70 \mathrm{~L} \cdot \mathrm{mol}^{-1} \cdot \mathrm{cm}^{-1}$. Absorbance at this wavelength was used to obtain the concentration of $\left[\mathrm{Cu}{ }^{\mathrm{II}} \mathrm{Br}(\mathrm{TPMA})\right]^{+}$.

When necessary, the concentration of $\left[\mathrm{Cu}^{\mathrm{II}}(\mathrm{R})(\mathrm{L})\right]^{+}$(for $\mathrm{R}=$ ester-based radical) was estimated by using $\varepsilon=162 \mathrm{~L} \cdot \mathrm{mol}^{-1} \cdot \mathrm{cm}^{-1}$ at $600 \mathrm{~nm}$ obtained for $\left[\mathrm{Cu}^{\mathrm{II}}\left(\mathrm{CH}_{2} \mathrm{COOEt}\right)(\mathrm{TPMA})\right]^{+}$in Figure S15. Note that the absorbance of ester- and cyano-based organocopper(II) species is very similar at $600 \mathrm{~nm}$.

\section{S2. “Termination” experiment of BAN}

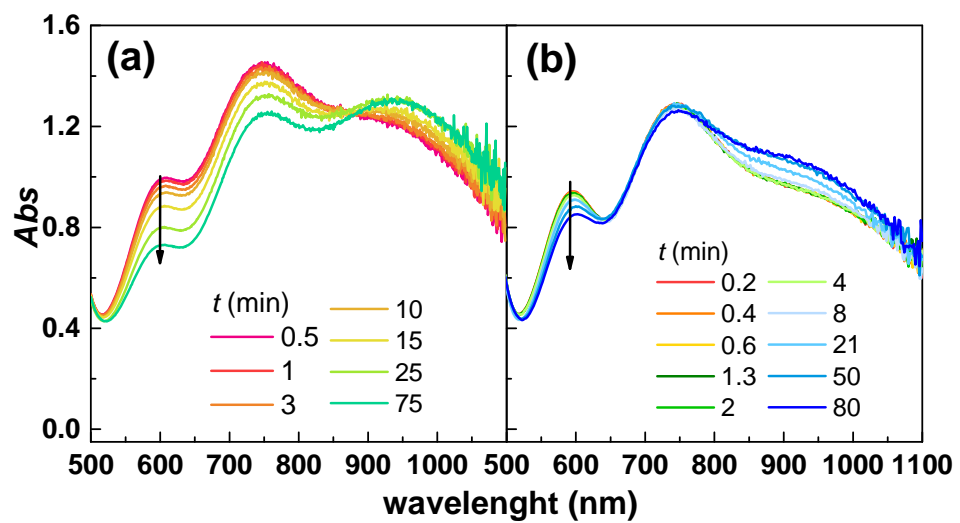

Figure S3. Vis-NIR spectra recorded during the reaction between (a) $10^{-2} \mathrm{M}\left[\mathrm{Cu}^{\mathrm{I}}(\mathrm{TPMA})\right]^{+} \mathrm{TfO}^{-}$

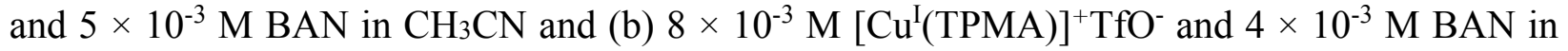
DMF, at room temperature. 


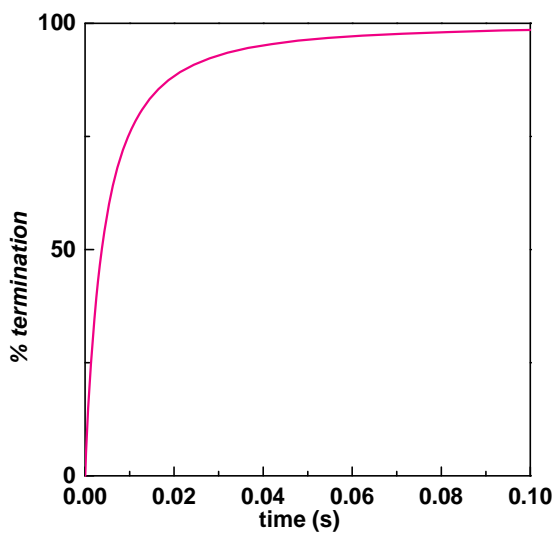

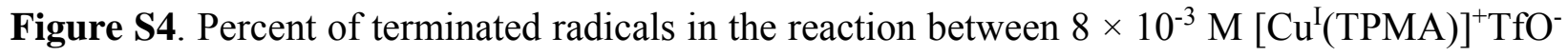
and $4 \times 10^{-3} \mathrm{M}$ BAN in DMF. OMRP trapping was switched off in the PREDICI simulation, based on the mechanism in Scheme 3 in the main text and Table S8 but without equations 4) and 6).

\section{S3. Detailed description of the electrochemical simulation procedure}

CVs were collected for each ATRP catalyst and initiator couple in the selected anhydrous solvent at 6 different scan rates $\left(0.05,0.075,0.1,0.2,0.5\right.$, and $\left.0.75 \mathrm{~V} \mathrm{~s}^{-1}\right)$ and 4 different $[\mathrm{RBr}] /[\mathrm{Cu}]$ ratios, which depended on the ATRP reactivity of the system. A first series of CVs in the absence of $\mathrm{Cu}$ complexes and $\mathrm{RBr}$ was recorded for each experiment to allow for the background subtraction in the simulation software. The simulations were conducted by using the model system reported in Table S1. The unknown parameters were:

i. the standard reduction potential and the heterogeneous constant of the electron transfer for $\left[\mathrm{Cu}^{\mathrm{II}}(\mathrm{R})(\mathrm{L})\right]^{+}\left(E_{\mathrm{R}}^{\ominus}, k_{\mathrm{R}}^{0}\right)$;

ii. the rate constant of ATRP deactivation, $k_{\mathrm{d}, \mathrm{ATRP}}$, and thus the equilibrium constant of ATRP, $K_{\text {ATRP; }}$

iii. both the rate constants of OMRP activation $\left(k_{\mathrm{a}, \mathrm{OMRP}}\right)$ and deactivation $\left(k_{\mathrm{d}, \mathrm{OMRP}}\right)$, and therefore also the equilibrium constant of OMRP, KOMRP;

iv. the dissociation constant of $\left[\mathrm{Cu}^{\mathrm{I}}(\mathrm{R})(\mathrm{L})\right], k_{\mathrm{dis}, \mathrm{R}}^{\mathrm{I}}$;

v. the rate constant of CRT, $k_{\mathrm{CRT}}$ (which was found to be relevant only for $\mathrm{RBr}=\mathrm{MBP}$, as explained in the main text).

All other parameters were measured independently or found in the literature, as it will be described in the following paragraphs. 
Table S1. Model system used for electrochemical simulations: reactions occurring in the system and relative parameters.

\begin{tabular}{|c|c|c|}
\hline & Reactions & Parameters $^{\mathrm{a}}$ \\
\hline & Electron transfers ${ }^{\mathrm{b}}$ & \\
\hline 1) & {$\left[\mathrm{Cu}^{\mathrm{II}}(\mathrm{L})\right]^{2+}+\mathrm{e}^{-}=\left[\mathrm{Cu}^{\mathrm{I}}(\mathrm{L})\right]^{+}$} & $E_{\mathrm{S}}^{\ominus}, k_{\mathrm{S}}^{0}$ \\
\hline 2) & {$\left[\mathrm{Cu}^{\mathrm{II}} \mathrm{Br}(\mathrm{L})\right]^{+}+\mathrm{e}^{-}=\left[\mathrm{Cu} \mathrm{u}^{\mathrm{I}} \mathrm{Br}(\mathrm{L})\right]$} & $E_{\mathrm{Br}}^{\ominus}, k_{\mathrm{Br}}^{0}$ \\
\hline \multirow[t]{2}{*}{ 3) } & {$\left[\mathrm{Cu}^{\mathrm{II}}(\mathrm{R})(\mathrm{L})\right]^{+}+\mathrm{e}^{-}=\left[\mathrm{Cu}^{\mathrm{I}}(\mathrm{R})(\mathrm{L})\right]$} & $E_{\mathrm{R}}^{\ominus}, k_{\mathrm{R}}^{0}$ \\
\hline & ATRP & \\
\hline \multirow[t]{2}{*}{ 4) } & {$\left[\mathrm{Cu}^{\mathrm{I}}(\mathrm{L})\right]^{+}+\mathrm{RBr}=\left[\mathrm{Cu}^{\mathrm{II}} \mathrm{Br}(\mathrm{L})\right]^{+}+\mathrm{R}^{\bullet}$} & $k_{\mathrm{a}, \mathrm{ATRP}}, \boldsymbol{k}_{\mathrm{d}, \mathrm{ATRP}}\left(\boldsymbol{K}_{\mathrm{ATRP}}\right)$ \\
\hline & $O M R P$ & \\
\hline \multirow[t]{2}{*}{ 5) } & {$\left[\mathrm{Cu}^{\mathrm{I}}(\mathrm{L})\right]^{+}+\mathrm{R}^{\bullet}=\left[\mathrm{Cu}^{\mathrm{II}}(\mathrm{R})(\mathrm{L})\right]^{+}$} & $k_{\mathrm{d}, \mathrm{OMRP}}, \boldsymbol{k}_{\mathrm{a}, \mathrm{OMRP}}\left(K_{\mathrm{OMRP}}\right)$ \\
\hline & Halidophilicity & \\
\hline 6) & {$\left[\mathrm{Cu}^{\mathrm{I}}(\mathrm{L})\right]^{+}+\mathrm{Br}^{-}=\left[\mathrm{Cu}^{\mathrm{I}} \mathrm{Br}(\mathrm{L})\right]$} & $k_{\mathrm{as}, \mathrm{Br}}^{\mathrm{I}}, k_{\mathrm{dis}, \mathrm{Br}}^{\mathrm{I}}\left(K_{\mathrm{Br}}^{\mathrm{I}}\right)$ \\
\hline \multirow[t]{2}{*}{ 7) } & {$\left[\mathrm{Cu}^{\mathrm{II}}(\mathrm{L})\right]^{2+}+\mathrm{Br}^{-}=\left[\mathrm{Cu}^{\mathrm{II}} \mathrm{Br}(\mathrm{L})\right]^{+}$} & $k_{\mathrm{as}, \mathrm{Br}}^{\mathrm{II}}, k_{\mathrm{dis}, \mathrm{Br}}^{\mathrm{II}}\left(K_{\mathrm{Br}}^{\mathrm{II}}\right)$ \\
\hline & Terminations & \\
\hline 8) & $\mathrm{R}^{\bullet}+\mathrm{R}^{\bullet} \rightarrow \mathrm{R}-\mathrm{R}$ & $k_{\mathrm{RT}}$ \\
\hline \multirow[t]{2}{*}{$10)^{\mathrm{c}}$} & {$\left[\mathrm{Cu}^{\mathrm{II}}(\mathrm{R})(\mathrm{L})\right]^{+}+\mathrm{R}^{\bullet} \rightarrow\left[\mathrm{Cu}^{\mathrm{I}}(\mathrm{L})\right]^{+}+$terminated chains } & $k_{\mathrm{CRT}}$ \\
\hline & Dissociation of $\left[C u^{I}(R)(L)\right]$ & \\
\hline 11$)^{\mathrm{d}}$ & {$\left[\mathrm{Cu}^{\mathrm{I}}(\mathrm{R})(\mathrm{L})\right] \rightarrow \mathrm{R}^{-}+\left[\mathrm{Cu}^{\mathrm{I}}(\mathrm{L})\right]^{+}$} & $\boldsymbol{k}_{\mathrm{dis}, \mathbf{R}}^{\mathrm{I}}$ \\
\hline
\end{tabular}

aparameters obtained from the simulation are written in bold. ${ }^{b}$ The charge transfer coefficient $\alpha$ was set to 0.5 for each electron transfer reaction. ${ }^{\text {cThe }} \mathrm{CRT}$ reaction resulted significant only for systems with $\mathrm{RBr}=\mathrm{MBP} .{ }^{\mathrm{d}} \mathrm{The}$ dissociation of $\left[\mathrm{Cu}^{\mathrm{II}}(\mathrm{R})(\mathrm{L})\right]^{+}\left(\left[\mathrm{Cu}{ }^{\mathrm{II}}(\mathrm{R})(\mathrm{L})\right]^{+} \rightarrow \mathrm{R}^{-}+\left[\mathrm{Cu}^{\mathrm{II}}(\mathrm{L})\right]^{2+}\right.$, with rate constant $\boldsymbol{k}_{\text {dis, }}^{\text {II }}$ ) was negligible.

In addition to the parameters in Table S1, the simulation software requires the knowledge of the diffusion coefficients $(D)$ of all the species in the model system. The diffusion coefficients of 
$\left[\mathrm{Cu}^{\mathrm{II}}(\mathrm{L})\right]^{2+}$ and $\left[\mathrm{Cu}^{\mathrm{II}} \mathrm{Br}(\mathrm{L})\right]^{+}$were determined from $\mathrm{CV}$ measurements, as described below. $D$ values in the order of $10^{-6} \mathrm{~cm}^{2} \mathrm{~s}^{-1}$ were obtained for all $\mathrm{Cu}$ catalysts in DMF, DMSO, and water, and about $1 \times 10^{-5} \mathrm{~cm}^{2} \mathrm{~s}^{-1}$ in $\mathrm{CH}_{3} \mathrm{CN}$, in agreement with previous reports. ${ }^{5,6}$ Typically $D\left(\left[\mathrm{Cu}^{\mathrm{II}} \mathrm{Br}(\mathrm{L})\right]^{+}\right)>D\left(\left[\mathrm{Cu}^{\mathrm{II}}(\mathrm{L})\right]^{2+}\right)$. The diffusion coefficients of $\mathrm{Cu}^{\mathrm{I}}$ complexes were set identical to those of the corresponding $\mathrm{Cu}^{\mathrm{II}}$ complexes, whereas $D$ values for the organometallic species were set identical to $D\left(\left[\mathrm{Cu}^{\mathrm{II}} \mathrm{Br}(\mathrm{L})\right]^{+}\right)$. $D$ values for the ATRP initiators were calculated according to previously reported formula, ${ }^{7}$ and resulted slightly higher than $D$ of ATRP catalysts. $D$ values of $\mathrm{R}^{\circ}, \mathrm{Br}^{-}, \mathrm{RR}$, TEMPO, and R-TEMPO were set similar to $D_{\mathrm{RBr}}$. It should be noted that $D$ values other than $D\left(\left[\mathrm{Cu}^{\mathrm{II}} \mathrm{Br}(\mathrm{L})\right]^{+}\right)$and $D_{\mathrm{RBr}}$ did not significantly affect the voltammetric response.

\section{S3.1. Electron transfer parameters, reactions 1) and 2)}

The reduction potential of $\left[\mathrm{Cu}{ }^{\mathrm{II}} \mathrm{Br}(\mathrm{L})\right]^{+}$was measured as $E_{\mathrm{Br}}^{\ominus}=E_{\mathrm{Br}, 1 / 2}=\left(E_{\mathrm{pa}}+E_{\mathrm{pc}}\right) / 2$ (where $E_{\mathrm{pa}}$ and $E_{\mathrm{pc}}$ are the anodic and cathodic peak potentials, respectively) by using the $\mathrm{CV}$ of $\left[\mathrm{Cu}{ }^{\mathrm{II}} \mathrm{Br}(\mathrm{L})\right]^{+}$in the absence of $\mathrm{RBr}$, recorded at a scan rate $=0.2 \mathrm{~V} \mathrm{~s}^{-1} . E_{\mathrm{Br}}^{\ominus}$ values were in good agreement $( \pm 0.005 \mathrm{~V})$ with previous reports. ${ }^{8-10}$

The reduction potential of binary complexes $\left[\mathrm{Cu}^{\mathrm{II}}(\mathrm{L})\right]^{2+}, E_{\mathrm{S}}^{\Theta}$, was measured in selected experiments by starting from a mixture of $\mathrm{L}$ and $\mathrm{Cu}^{\mathrm{II}}(\mathrm{OTf})_{2}$, instead of $\mathrm{Cu}^{\mathrm{II}} \mathrm{Br}_{2}$. These $\mathrm{CV}$ s allowed for determining $E_{\mathrm{S}}^{\ominus}$ as described in the preceding paragraph. $E_{\mathrm{S}}^{\ominus}$ values were in good agreement $( \pm$ $0.005 \mathrm{~V}$ ) with previous reports. ${ }^{8,10-12}$

$\mathrm{CVs}$ of $\left[\mathrm{Cu}{ }^{\mathrm{II}} \mathrm{Br}(\mathrm{L})\right]^{+}$and $\left[\mathrm{Cu}{ }^{\mathrm{II}}(\mathrm{L})\right]^{2+}$ at different scan rates allowed the determination of the diffusion coefficients of these species by measuring the cathodic peak current $I_{\mathrm{pc}}$ at each scan rate $(v)$ and applying the following equation, known as Randles-Sevcik equation: ${ }^{5,6,13}$

$$
I_{\mathrm{pc}}=0.4463 n F A C\left(\frac{n F v D}{R T}\right)^{1 / 2}
$$

where $\mathrm{n}$ is the number of electrons in the electron transfer reaction, $F$ is Faraday's constant, $R$ is the gas constant, $T$ is the temperature, $C$ is the concentration of the redox active species, and $A$ is the electrode area.

By using the same series of CVs it was also possible to measure the heterogeneous rate constants of the electron transfer for $\left[\mathrm{Cu}^{\mathrm{II}} \mathrm{Br}(\mathrm{L})\right]^{+}$and $\left[\mathrm{Cu}^{\mathrm{II}}(\mathrm{L})\right]^{2+}, k_{\mathrm{Br}}^{0}$ and $k_{\mathrm{S}}^{0}$ respectively, thorough the Nicholson's method. ${ }^{13}$ This method correlates the variation in the difference between 
the anodic and cathodic peak potentials with changing the scan rate to the rate of the electron transfer. $k^{0}$ values ranging between $0.02-0.04 \mathrm{~cm} \mathrm{~s}^{-1}$ were obtained for all $\mathrm{Cu}$ complexes.

\section{S3.2. Halidophilicity constants, reactions 6) and 7)}

The thermodynamic halidophilicity constant for $\left[\mathrm{Cu}^{\mathrm{II}}(\mathrm{L})\right]^{2+}, K_{\mathrm{Br}}^{\mathrm{II}}$, was measured by spectrophotometric titrations, according to a previously reported procedure. ${ }^{14,15}$ Figure S5a shows the Vis-NIR spectra obtained for the titration of a solution of $\left[\mathrm{Cu}^{\mathrm{II}}(\mathrm{TPMA})\right]^{2+}$ in DMF with consecutive additions of known amounts of a solution of $\mathrm{Et}_{4} \mathrm{NBr}$ in DMF. The values of $K_{\mathrm{Br}}^{\mathrm{II}}$ used in this work are reported in Table S2.
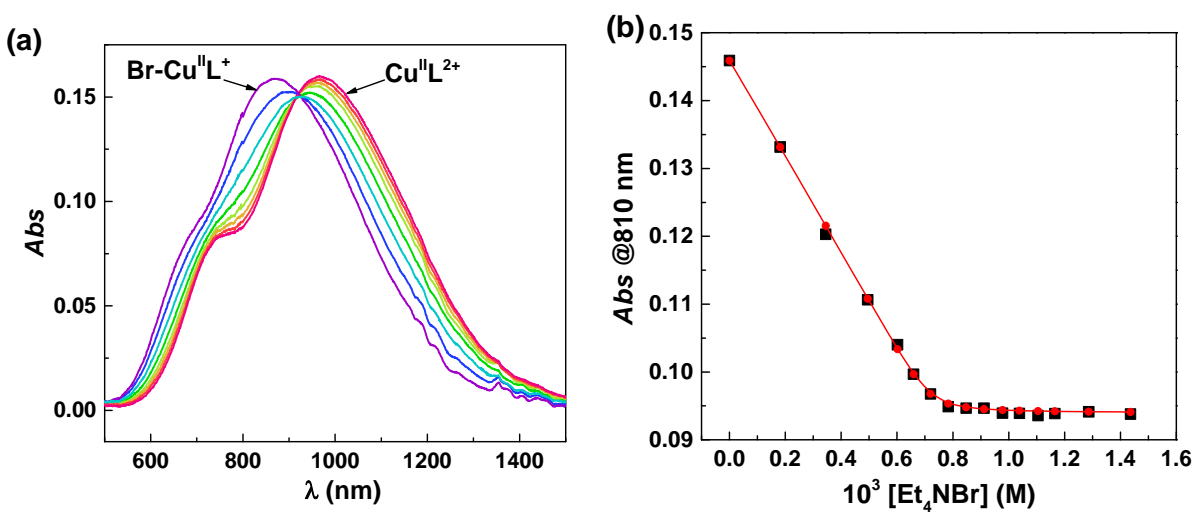

Figure S5. (a) Vis-NIR spectra recorded during the titration of $0.7 \mathrm{mM} \mathrm{Cu}^{\mathrm{II}}(\mathrm{OTf})_{2} / \mathrm{TPMA}$ in DMF with aliquots of a stock solution of $\mathrm{Et}_{4} \mathrm{NBr}$ in DMF. (b) Best fit curve (in red) of experimental data (black squares) of absorbance at $810 \mathrm{~nm}$.

Table S2. Thermodynamic halidophilicity constants for $\left[\mathrm{Cu}{ }^{\mathrm{II}}(\mathrm{L})\right]^{2+}$ used in the electrochemical simulations.

\begin{tabular}{lllll}
\hline Entry & $\mathrm{L}$ & Solvent & $K_{\mathrm{Br}}^{\mathrm{II}}\left(\mathrm{M}^{-1}\right)$ & Ref. \\
\hline 1 & TPMA & $\mathrm{CH}_{3} \mathrm{CN}$ & $3.4 \times 10^{7}$ & 4 \\
2 & TPMA & DMF & $(4.2 \pm 0.6) \times 10^{5}$ & This work \\
3 & TPMA & DMSO & $(1.0 \pm 0.2) \times 10^{5}$ & This work \\
4 & TPMA & $\mathrm{H}_{2} \mathrm{O}$ & $8.1 \pm 1.2$ & 8 \\
5 & TPMA $^{* 3}$ & DMF & $(4.2 \pm 0.6) \times 10^{5}$ & This work \\
6 & TPMA $^{\mathrm{NMe} 2}$ & DMF & $(1.2 \pm 0.2) \times 10^{5}$ & This work \\
\hline
\end{tabular}


Once measured $K_{\mathrm{Br}}^{\mathrm{II}}$, the thermodynamic halidophilicity constant for $\left[\mathrm{Cu}^{\mathrm{I}}(\mathrm{L})\right]^{+}, K_{\mathrm{Br}}^{\mathrm{I}}$, is obtained from equation $\mathrm{S} 1:^{14}$

$K_{\mathrm{Br}}^{\mathrm{I}}=K_{\mathrm{Br}}^{\mathrm{II}}+\frac{F}{R T} e^{\left(E_{\mathrm{Br}}^{\ominus}-E_{\mathrm{S}}^{\ominus}\right)}$

Concerning the kinetics of $\mathrm{Br}^{-}$association and dissociation, it is known that $\left[\mathrm{Cu}{ }^{\mathrm{II}} \mathrm{Br}(\mathrm{L})\right]^{+}$is very stable in organic solvents: speciation studies showed that $\left[\mathrm{Cu}^{\mathrm{II}} \mathrm{Br}(\mathrm{L})\right]^{+}$is the only species significantly present in the system when $[\mathrm{Br}]:[\mathrm{Cu}] \geq 2 .{ }^{14}$ Therefore, $k_{\mathrm{as}, \mathrm{Br}}^{\mathrm{II}}$ was always set as $10^{7}$ $\mathrm{M}^{-1} \mathrm{~s}^{-1}$, such as to have $k_{\mathrm{dis}, \mathrm{Br}}^{\mathrm{II}} \leq 10^{2} \mathrm{~s}^{-1}$. Indeed, values of $k_{\mathrm{as}, \mathrm{Br}}^{\mathrm{II}}>10^{7} \mathrm{M}^{-1} \mathrm{~s}^{-1}$ were observed to not produce any changes in the simulated CVs. Conversely, in water $\left[\mathrm{Cu}{ }^{\mathrm{II}} \mathrm{Br}(\mathrm{L})\right]^{+}$tends to dissociate to $\mathrm{Br}^{-}$and $\left[\mathrm{Cu}^{\mathrm{II}}(\mathrm{L})\right]^{2+}$ with an equilibrium constant $K_{\mathrm{Br}}^{\mathrm{II}}=8.1 \mathrm{M}^{-1} \cdot{ }^{8}$ Combining this value with $k_{\mathrm{as}, \mathrm{Br}}^{\mathrm{II}}=10^{7} \mathrm{M}^{-1} \mathrm{~s}^{-1}$ gave $k_{\mathrm{dis}, \mathrm{Br}}^{\mathrm{II}}=1.2 \times 10^{6} \mathrm{~s}^{-1}$.

For $\mathrm{Cu}(\mathrm{I})$ species, we considered that $k_{\mathrm{dis}, \mathrm{Br}}^{\mathrm{I}}$ has a crucial effect on the determination of the ATRP activation rate constant, $k_{\mathrm{a}, \mathrm{ATRP}}$. Indeed, for determining $k_{\mathrm{a}, \mathrm{ATRP}}$, TEMPO is added to the system to kinetically isolate the activation step (see the main text and Section S3.3) and CVs are recorded at different scan rates and $[\mathrm{RBr}]:[\mathrm{Cu}]$ ratios. The observed enhancement in the cathodic current with increasing the $[\mathrm{RBr}]:[\mathrm{Cu}]$ ratio strongly depends on the availability of the ATRP activator $\left[\mathrm{Cu}^{\mathrm{I}}(\mathrm{L})\right]^{+}$and therefore on the extent of the dissociation of $\mathrm{Br}^{-}$from $\left[\mathrm{Cu}^{\mathrm{I}} \mathrm{Br}(\mathrm{L})\right]$. Therefore, low values of $k_{\mathrm{dis,Br}}^{\mathrm{I}}$ can limit the catalytic current (Figure S6), particularly in the case of high ATRP reactivity (i.e. highly reactive $\mathrm{RBr}$ and/or very active catalysts). Thus, selected experiments for $k_{\mathrm{a}, \mathrm{ATRP}}$ determination (see Table S3) were performed with extremely reactive $\mathrm{RBr}$ without fixing the values of $k_{\mathrm{a}, \mathrm{ATRP}}$ and $k_{\mathrm{as}, \mathrm{Br}}^{\mathrm{I}}$. The resulting values of $k_{\mathrm{as}, \mathrm{Br}}^{\mathrm{I}}$ (Table S3) represented a lower limit for that parameter: indeed, we verified that fixed higher values of $k_{\mathrm{dis}, \mathrm{Br}}^{\mathrm{I}}$ (up to the diffusion limit for the analyzed catalyst in the selected solvent) did not modify the CV curves and the obtained $k_{\mathrm{a}, \mathrm{ATRP}}$ (the variation was within the error range).

Table S3. Kinetic halidophilicity constants for $\left[\mathrm{Cu}^{\mathrm{I}}(\mathrm{L})\right]^{+}$used in the electrochemical simulations and obtained from ATRP activation experiments.

\begin{tabular}{llllll}
\hline Entry & $\mathrm{L}$ & Solvent & $\mathrm{RBr}$ & $k_{\mathrm{as}, \mathrm{Br}}^{\mathrm{I}}\left(\mathrm{M}^{-1} \mathrm{~s}^{-1}\right)$ & $k_{\mathrm{dis}, \mathrm{Br}}^{\mathrm{I}}\left(\mathrm{s}^{-1}\right)$ \\
\hline $1^{\mathrm{a}}$ & TPMA & $\mathrm{CH}_{3} \mathrm{CN}$ & EBPA & $>5 \times 10^{7}$ & $>3 \times 10^{4}$
\end{tabular}




$\begin{array}{llllll}2 & \text { TPMA } & \text { DMF } & \text { BPN } & >1 \times 10^{7} & >7 \times 10^{2} \\ 3^{\mathrm{a}} & \text { TPMA } & \text { DMSO } & \text { BPN } & >1 \times 10^{7} & >2 \times 10^{3} \\ 4 & \text { TPMA } & \mathrm{H}_{2} \mathrm{O} & \mathrm{MBP} & >1 \times 10^{7} & >1 \times 10^{6} \\ 5 & \text { TPMA }^{*} 3 & \text { DMF } & \text { MBP } & >1 \times 10^{8} & >3 \times 10^{4} \\ 6 & \text { TPMA }^{\text {NMe2 }} & \text { DMF } & \text { MBP } & >5 \times 10^{8} & >2 \times 10^{6}\end{array}$

${ }^{a}$ Bernhardt et al. reported $k_{\mathrm{as}, \mathrm{Br}}^{\mathrm{I}}=5.7 \times 10^{5} \mathrm{M}^{-1} \mathrm{~s}^{-1}$ and $7.6 \times 10^{5} \mathrm{M}^{-1} \mathrm{~s}^{-1}$ for $\mathrm{L}=\mathrm{TPMA}$ in $\mathrm{CH}_{3} \mathrm{CN}$ and DMSO, respectively. ${ }^{4}$
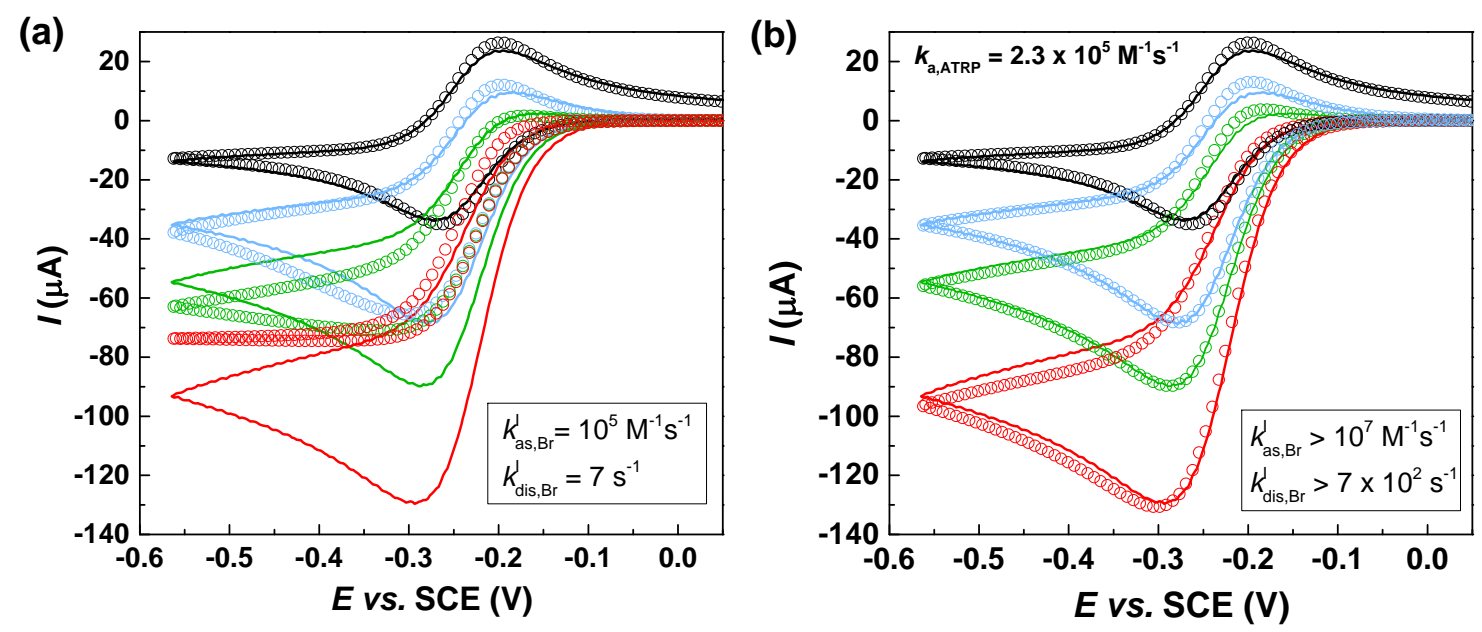

Figure S6. Experimental (lines) and simulated (circles) CVs of $2 \times 10^{-3} \mathrm{M} \mathrm{Cu}^{\mathrm{II}} \mathrm{Br}_{2}+2.2 \times 10^{-3} \mathrm{M}$ TPMA in DMF + 0.1 M Et $4 \mathrm{NBF}_{4}$ and 0.05 M TEMPO, in the absence (black) and presence of 2 (light blue), 4 (green), 10 (red) $\mathrm{mM} \mathrm{BPN}$, scan rate $=0.2 \mathrm{~V} \mathrm{~s}^{-1}, T=25^{\circ} \mathrm{C}$.

\section{S3.3. Determination of $k_{\mathrm{a}, \mathrm{ATRP}}$, reaction 4)}

The activation rate constant of ATRP, $k_{\mathrm{a}, \mathrm{ATRP}}$, was determined according to a well-established electrochemical procedure. ${ }^{5,6}$ A series of $\mathrm{CVs}$ of $\left[\mathrm{Cu}^{\mathrm{II}} \mathrm{Br}(\mathrm{L})\right]^{+}$was collected at different scan rates and $[\mathrm{RBr}]:[\mathrm{Cu}]$ ratios, in the presence of a large excess of the radical scavenger TEMPO ([TEMPO]: $[\mathrm{Cu}]=25-50)$. Under these conditions, TEMPO trapped all generated radicals, which could not be trapped either by $\left[\mathrm{Cu}^{\mathrm{II}} \mathrm{Br}(\mathrm{L})\right]^{+}$(ATRP deactivation) or $\left[\mathrm{Cu}^{\mathrm{I}}(\mathrm{L})\right]^{+}$(OMRP deactivation). Therefore, the ATRP activation step was kinetically isolated.

The experimental CVs were then simulated by using a simpler model than the one reported in Table S1: indeed, in the presence of a radical trap no organometallic species is generated and the 
ATRP equilibrium becomes irreversible, thus the model reduces to the set of reactions in Table $\mathrm{S} 4$, which includes the termination by TEMPO (T) trapping. $k_{\mathrm{a}, \mathrm{ATRP}}$ was the only unknown parameter, except in the case of simultaneous determination of $k_{\mathrm{a}, \mathrm{ATRP}}$ and $k_{\mathrm{dis}, \mathrm{Br}}^{\mathrm{I}}$ (described in Section S3.2).

The experimental and simulated CVs for each catalyst-RBr couple in different solvents at a selected scan rate are reported in Section S4. $k_{\mathrm{a}, \mathrm{ATRP}}$ was typically slightly higher than $k_{\mathrm{a}, \mathrm{ATRP}}$ values for identical systems measured with different electrochemical techniques. ${ }^{5,9}$ To be consistent, in this work every $k_{\mathrm{a}, \mathrm{ATRP}}$ values was determined by $\mathrm{CV}$ simulation, except for $\left[\mathrm{Cu}^{\mathrm{I}}(\mathrm{TPMA})\right]^{+}$and MBP in DMSO and water. $k_{\mathrm{a}, \mathrm{ATRP}}$ for this system in DMSO was measured through a rotating disk electrode according to a reported procedure ${ }^{16}$ and the obtained value ( $k_{\mathrm{a}, \mathrm{ATRP}}$ $=4100 \mathrm{M}^{-1} \mathrm{~s}^{-1}$ ) was rescaled as to match the same trend observed in other solvents. In water, $k_{\mathrm{a}, \mathrm{ATRP}}$ was set as an unknown parameter: the obtained value $\left(k_{\mathrm{a}, \mathrm{ATRP}}=5.5 \times 10^{5} \mathrm{M}^{-1} \mathrm{~s}^{-1}\right)$ is in $\operatorname{good}$ agreement with previously reported values for similar initiators. ${ }^{8}$

Table S4. Model system used for the electrochemical simulations of ATRP activation.

\begin{tabular}{|c|c|c|}
\hline & Reactions & Parameters \\
\hline & Electron transfers & \\
\hline 1) & {$\left[\mathrm{Cu}^{\mathrm{II}}(\mathrm{L})\right]^{2+}+\mathrm{e}^{-}=\left[\mathrm{Cu}^{\mathrm{I}}(\mathrm{L})\right]^{+}$} & $E_{\mathrm{S}}^{\Theta}, k_{\mathrm{S}}^{0}$ \\
\hline \multirow[t]{2}{*}{ 2) } & {$\left[\mathrm{Cu}^{\mathrm{II}} \mathrm{Br}(\mathrm{L})\right]^{+}+\mathrm{e}^{-}=\left[\mathrm{Cu}^{\mathrm{I}} \mathrm{Br}(\mathrm{L})\right]$} & $E_{\mathrm{Br}}^{\Theta}, k_{\mathrm{Br}}^{0}$ \\
\hline & ATRP activation & \\
\hline \multirow[t]{2}{*}{ 3) } & {$\left[\mathrm{Cu}^{\mathrm{I}}(\mathrm{L})\right]^{+}+\mathrm{RBr} \rightarrow\left[\mathrm{Cu}^{\mathrm{II}} \mathrm{Br}(\mathrm{L})\right]^{+}+\mathrm{R}^{\bullet}$} & $k_{\mathrm{a}, \mathrm{ATRP}}$ \\
\hline & Halidophilicity & \\
\hline 4) & {$\left[\mathrm{Cu}^{\mathrm{I}}(\mathrm{L})\right]^{+}+\mathrm{Br}^{-}=\left[\mathrm{Cu}^{\mathrm{I}} \mathrm{Br}(\mathrm{L})\right]$} & $k_{\mathrm{as}, \mathrm{Br}}^{\mathrm{I}}, k_{\mathrm{dis}, \mathrm{Br}}^{\mathrm{I}}\left(K_{\mathrm{Br}}^{\mathrm{I}}\right)$ \\
\hline \multirow[t]{2}{*}{ 5) } & {$\left[\mathrm{Cu}^{\mathrm{II}}(\mathrm{L})\right]^{2+}+\mathrm{Br}^{-}=\left[\mathrm{Cu}^{\mathrm{II}} \mathrm{Br}(\mathrm{L})\right]^{+}$} & $k_{\mathrm{as}, \mathrm{Br}}^{\mathrm{II}}, k_{\mathrm{dis}, \mathrm{Br}}^{\mathrm{II}}\left(K_{\mathrm{Br}}^{\mathrm{II}}\right)$ \\
\hline & Terminations & \\
\hline 6) & $\mathrm{R}^{\bullet}+\mathrm{R}^{\bullet} \rightarrow \mathrm{R}-\mathrm{R}$ & $k_{\mathrm{RT}}$ \\
\hline 7) & $\mathrm{R}^{\bullet}+\mathrm{T}^{\bullet} \rightarrow \mathrm{R}-\mathrm{T}$ & $k_{\mathrm{c}}$ \\
\hline
\end{tabular}




\section{S3.4. Termination rate constants, reactions 8) and 9)}

The rate constant of conventional radical termination, $k_{\mathrm{RT}}$, was taken from the literature and varied with the solvent nature. ${ }^{11}$ Small changes in $k_{\mathrm{RT}}$ values do not affect much the CV response.

Table S5. Conventional radical termination rate constants used in this work.

\begin{tabular}{lll}
\hline Entry & Solvent & $k_{\mathrm{RT}}\left(\mathrm{M}^{-1} \mathrm{~s}^{-1}\right)$ \\
\hline 1 & $\mathrm{CH}_{3} \mathrm{CN}$ & $3.6 \times 10^{9}$ \\
2 & $\mathrm{DMF}$ & $1.7 \times 10^{9}$ \\
3 & $\mathrm{DMSO}$ & $8.4 \times 10^{8}$ \\
$4^{\mathrm{a}}$ & $\mathrm{H}_{2} \mathrm{O}$ & $1.7 \times 10^{9}$
\end{tabular}

${ }^{\mathrm{a}} k_{\mathrm{RT}}$ in water was not available in the literature and therefore we used the same value used in DMF.

The termination rate constant of radicals with TEMPO was set as $k_{\mathrm{c}}=10^{9} \mathrm{M}^{-1} \mathrm{~s}^{-1}$. Although this value may slightly change with the solvent nature, its variation did not affect the $\mathrm{CV}$ response because TEMPO was present in a large excess with respect to the $\mathrm{Cu}$ catalyst ([TEMPO]:[Cu] $=$ 25-50).

\section{S3.5. Calculation of Diffusion-Limited $k_{\mathrm{d}, \mathrm{OMRP}}$}

For the cases of $\mathrm{Cu}^{\mathrm{II}} \mathrm{Br}_{2} / \mathrm{TPMA}+\mathrm{BPN}$ in DMF, and $\mathrm{Cu}^{\mathrm{II}} \mathrm{Br}_{2} / \mathrm{TPMA}+\mathrm{MBP}$ in DMF and water, the $\mathrm{CV}$ simulations were returning unreasonable values of $k_{\mathrm{d} \text {,OMRP, }}$, higher than the diffusion limit for a second order reaction. Therefore, in these cases the value of $k_{\mathrm{d} \text {,OMRP }}$ was set to the diffusion-limit for a second order reaction, which was calculated on the basis of the Smoluchowski equation, treating the reaction as a radical-trap reaction. ${ }^{11,17}$

$$
k_{\text {diff }}=10^{-3} \times \pi \times N_{\mathrm{A}} \times\left(D_{\mathrm{Cu}}+D_{\mathrm{R}}\right) \times\left(r_{\mathrm{Cu}}+r_{\mathrm{R}}\right)
$$

where $N_{\mathrm{A}}$ is the Avogadro's Number, $D_{\mathrm{Cu}}$ and $D_{\mathrm{R}}$ are the diffusion coefficients of $\left[\mathrm{Cu}^{\mathrm{I}}(\mathrm{L})\right]^{+}$and $\mathrm{R}^{*}$, and $r_{\mathrm{Cu}}+r_{\mathrm{R}}$ is the reaction distance (i.e. the sum of molecular radii).

$D_{\mathrm{R}}$ was assumed equal to $D_{\mathrm{RBr}}$, which was calculated as described in the literature for DMF (the same diffusion coefficient was considered for DMF and water, due to similar viscosities). ${ }^{7}$

$D_{\mathrm{Cu}}$ was obtained from the $\mathrm{CV}$ of $\mathrm{Cu}^{\mathrm{II}} \mathrm{Br} 2 / \mathrm{TPMA}$ as explained above. 
$r_{\mathrm{R}}$ was calculated from the molecular volume of methyl propionate, assuming that the methyl propionate radical has a similar size to methyl propionate, on the basis of the following formula: ${ }^{11}$

$$
2 r_{R}=\left(\frac{M}{d \times N_{A}}\right)^{1 / 3}
$$

where $\mathrm{M}$ and $d$ are the molecular weight and the density of methyl propionate.

$r_{\mathrm{Cu}}$ was determined from crystallographic data. ${ }^{18}$ This has been done as follows. The volume of a crystal cell containing 8 molecules of $\mathrm{Cu}{ }^{\mathrm{I}} \mathrm{Cl} / \mathrm{TPMA}$ is $\mathrm{V}=3703.7 \AA^{3}$, which gives a mean molecular volume of $463 \AA^{3}$. Assuming the molecules have spherical shape, we obtain a radius $r$ $=4.8 \AA(\mathrm{d}=9.6 \AA)$, that we can assume to be valid for $\left[\mathrm{Cu}^{\mathrm{I}}(\mathrm{TPMA})\right]^{+}$.

An example of calculation is reported for the $\mathrm{Cu}^{\mathrm{II}} \mathrm{Br}_{2} / \mathrm{TPMA}+\mathrm{MBP}$ system in water:

$D_{\mathrm{R}}=1.4 \times 10^{-5} \mathrm{~cm}^{2} \mathrm{~s}^{-1}, D_{\mathrm{Cu}}=7.5 \times 10^{-6} \mathrm{~cm}^{2} \mathrm{~s}^{-1}, r_{\mathrm{R}}=2.7 \times 10^{-8} \mathrm{~cm}, r_{\mathrm{Cu}}=4.8 \times 10^{-8} \mathrm{~cm}, k_{\text {diff }}=1.5$ $\times 10^{9} \mathrm{M}^{-1} \mathrm{~s}^{-1}$.

\section{S4. Experimental and simulated CVs for $\boldsymbol{k}_{\mathrm{a}, \mathrm{ATRP}}$ determination.}

\section{S4.1. ATRP initiators}

$\mathrm{L}=\mathrm{TPMA}$, solvent $=\mathrm{DMF}$ 

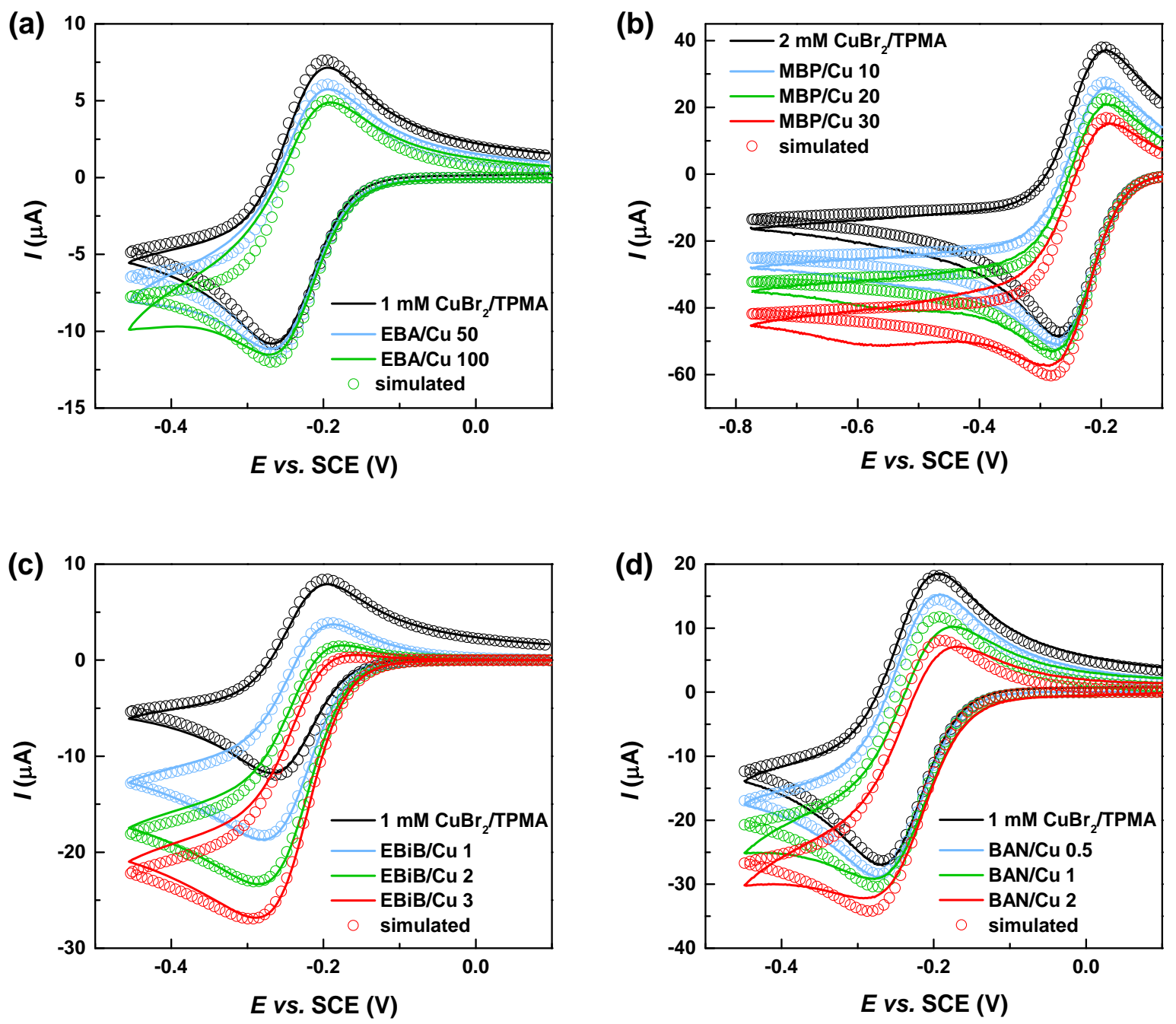

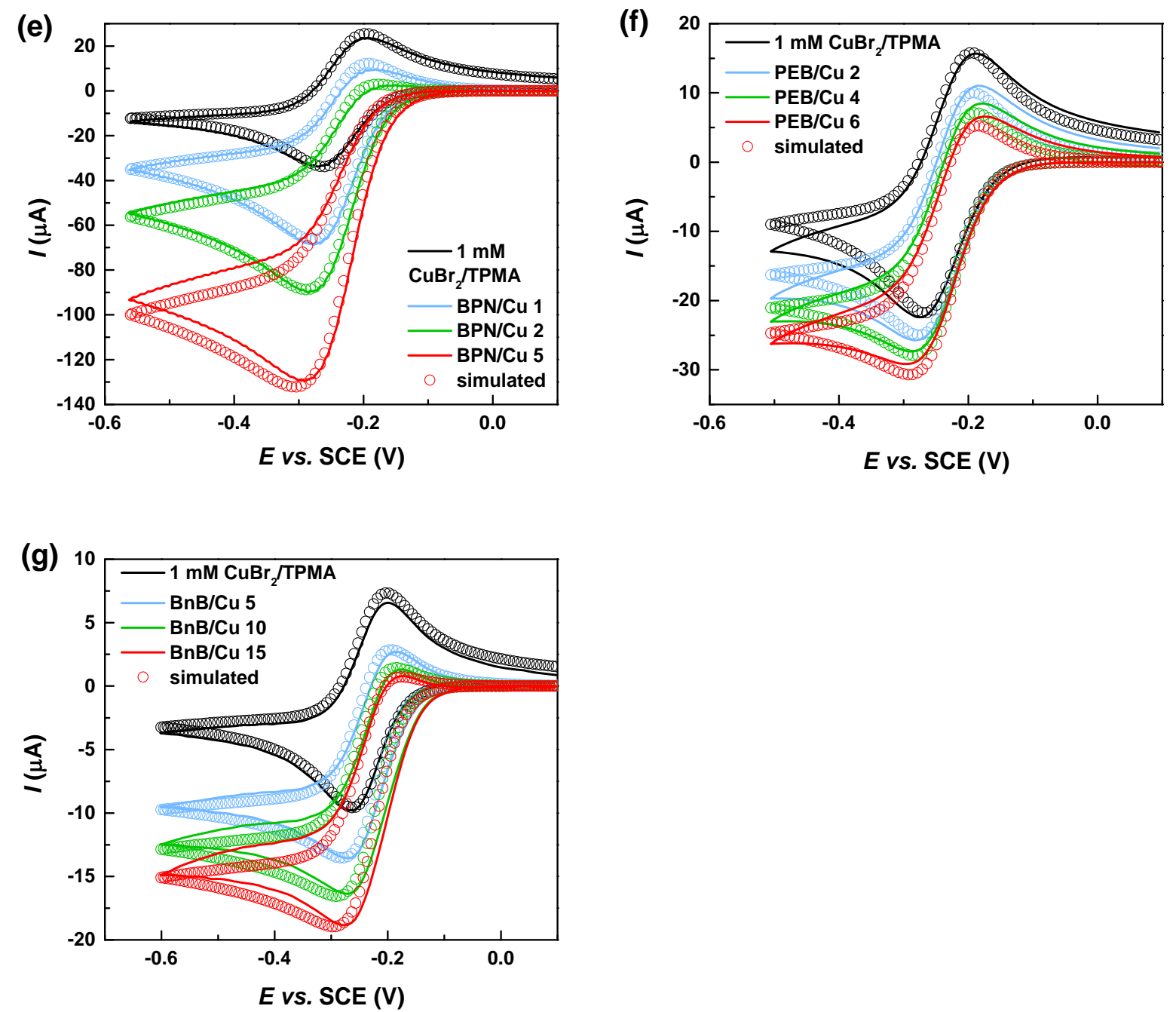

Figure S7. Experimental (lines) and simulated (circles) $\mathrm{CVs}$ for $1 \mathrm{mM} \mathrm{Cu}{ }^{\mathrm{II}} \mathrm{Br}_{2}+1.1 \mathrm{mM}$ TPMA in $\mathrm{DMF}+0.1 \mathrm{MEt}_{4} \mathrm{NBF}_{4}+0.05 \mathrm{M}$ TEMPO, in the absence and presence of increasing amounts of $\mathrm{RBr}, T=25^{\circ} \mathrm{C}$. (a) $\mathrm{RBr}=\mathrm{EBA}$, scan rate $=0.075 \mathrm{~V} \mathrm{~s}^{-1}$, (b) $\mathrm{RBr}=\mathrm{MBP}$, scan rate $=0.5 \mathrm{~V} \mathrm{~s}^{-1}$, (c) $\mathrm{RBr}=\mathrm{EBiB}$, scan rate $=0.1 \mathrm{~V} \mathrm{~s}^{-1}$, (d) $\mathrm{RBr}=\mathrm{BAN}$, scan rate $=0.2 \mathrm{~V} \mathrm{~s}^{-1}$, (e) $\mathrm{RBr}=\mathrm{BPN}$, scan rate $=0.2 \mathrm{~V} \mathrm{~s}^{-1}$, (f) $\mathrm{RBr}=\mathrm{PEB}$, scan rate $=0.2 \mathrm{~V} \mathrm{~s}^{-1},(\mathrm{~g}) \mathrm{RBr}=\mathrm{BnB}$, scan rate $=0.05 \mathrm{~V} \mathrm{~s}^{-1}$. In (b): $2 \mathrm{mM} \mathrm{Cu}{ }^{\mathrm{II}} \mathrm{Br}_{2}+2.2 \mathrm{mM}$ TPMA. 


\section{S4.2. ATRP catalysts}
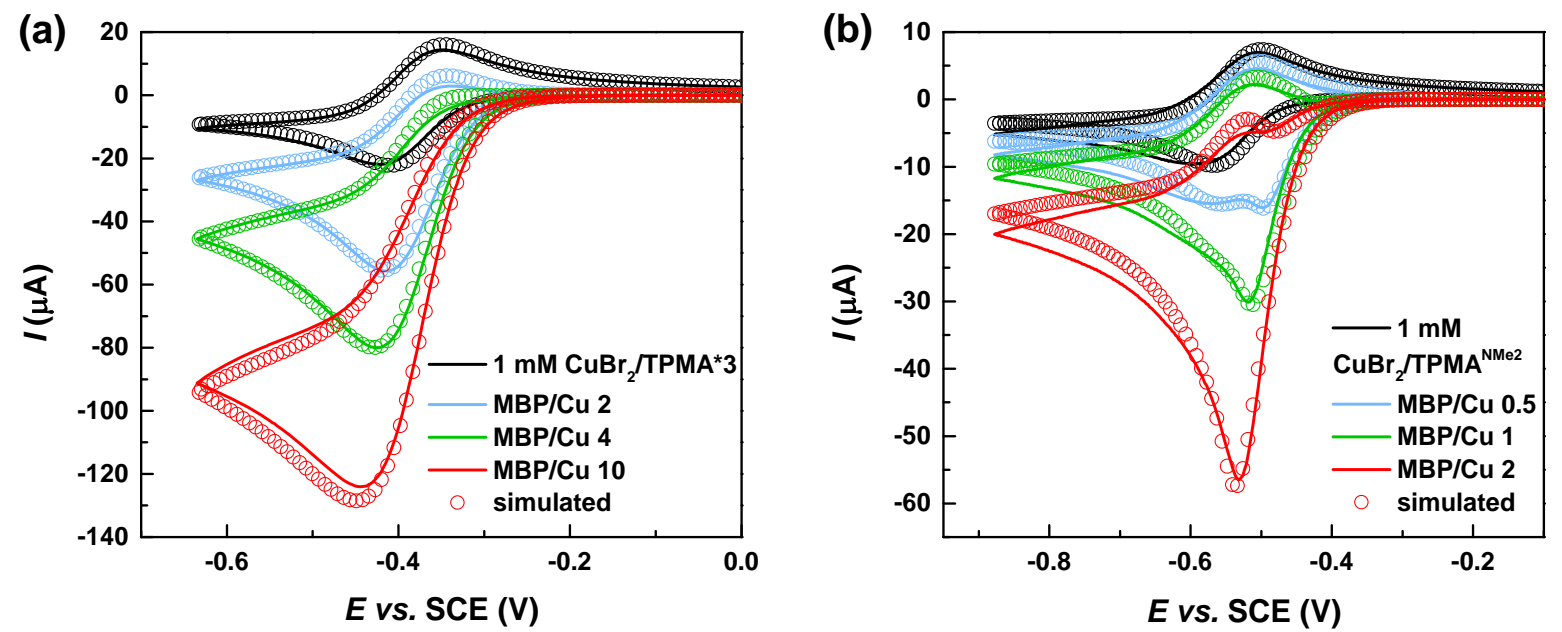

Figure S8. Experimental (lines) and simulated (circles) $\mathrm{CVs}$ for $1 \mathrm{mM} \mathrm{Cu}^{\mathrm{II}} \mathrm{Br}_{2}+1.1 \mathrm{mM}$ (a) TPMA*3, (b) $\mathrm{TPMA}^{\mathrm{NMe} 2}$ in $\mathrm{DMF}+0.1 \mathrm{M} \mathrm{Et}_{4} \mathrm{NBF}_{4}+0.05 \mathrm{M}$ TEMPO, in the absence and presence of increasing amounts of MBP. Scan rate $=\left(\right.$ a) 0.2 , (b) $0.1 \mathrm{~V} \mathrm{~s}^{-1}, T=25^{\circ} \mathrm{C}$.

\section{S4.3. Solvents}
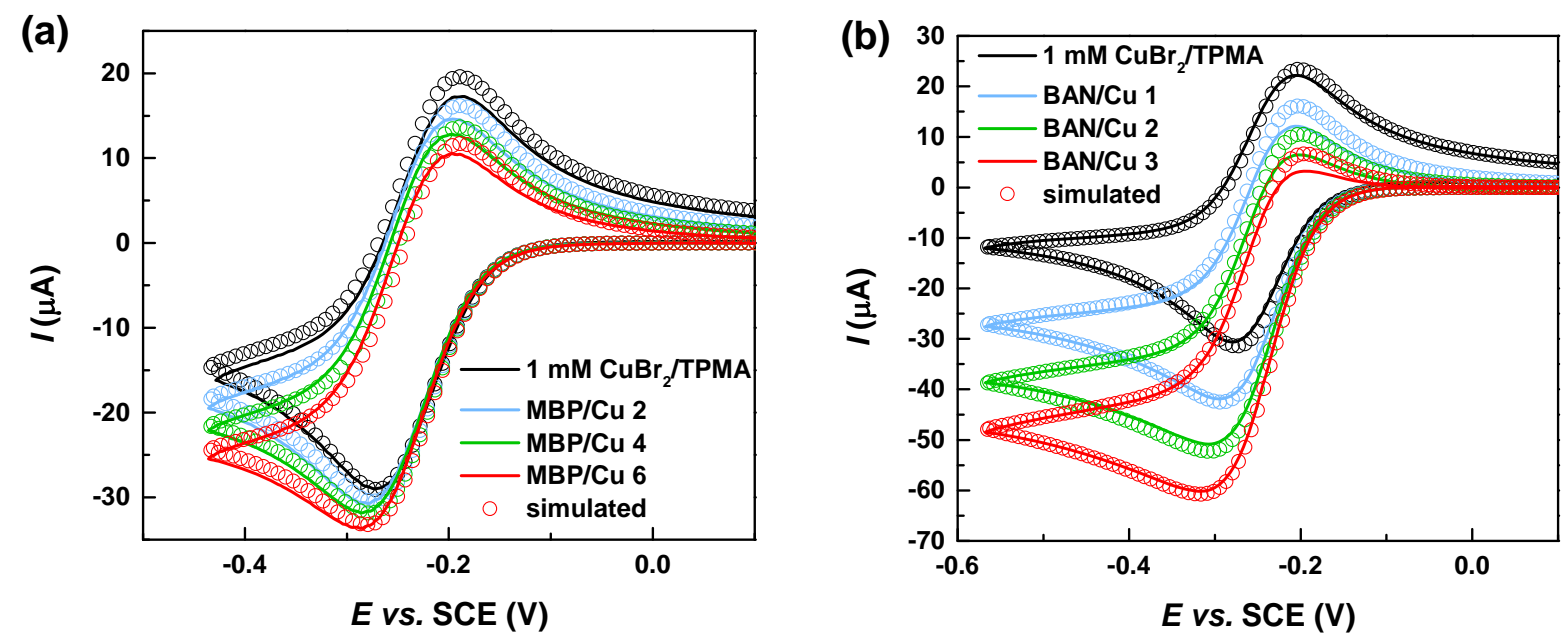

Figure S9. Experimental (lines) and simulated (circles) $\mathrm{CVs}$ for $1 \mathrm{mM} \mathrm{Cu}{ }^{\mathrm{II}} \mathrm{Br}_{2}+1.1 \mathrm{mM}$ TPMA in $\mathrm{CH}_{3} \mathrm{CN}+0.1 \mathrm{M} \mathrm{Et}_{4} \mathrm{NBF}_{4}+0.05 \mathrm{M}$ TEMPO, in the absence and presence of increasing amounts of (a) MBP, and (b) BAN. Scan rate $=0.2 \mathrm{~V} \mathrm{~s}^{-1}, T=25^{\circ} \mathrm{C}$. 


\section{S5. Electrochemical analysis of the stability of $\mathrm{R}-\mathrm{Cu} / \mathrm{L}$ intermediates}

\section{S5.1. ATRP (macro)initiators}

$\mathrm{L}=\mathrm{TPMA}$, solvent $=\mathrm{DMF}$
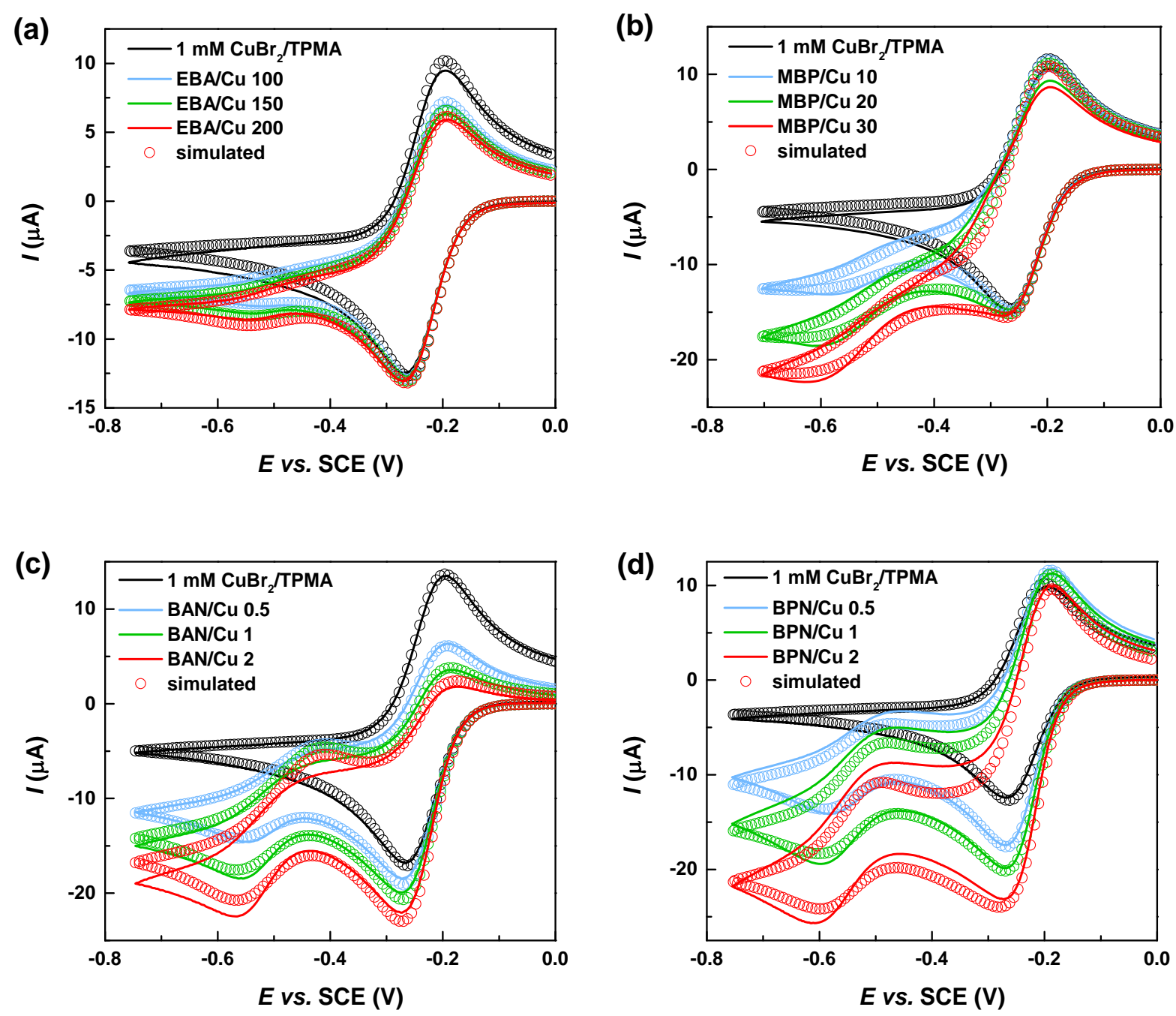


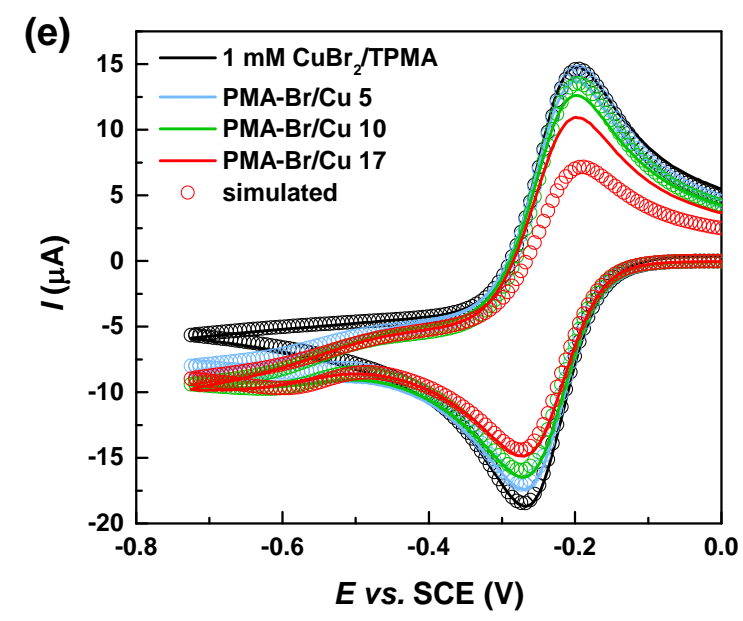

Figure S10. Experimental (lines) and simulated (circles) $\mathrm{CVs}$ for $1 \mathrm{mM} \mathrm{Cu}{ }^{\mathrm{II}} \mathrm{Br}_{2}+1.1 \mathrm{mM}$ TPMA in $\mathrm{DMF}+0.1 \mathrm{MEt}_{4} \mathrm{NBF}_{4}$, in the absence and presence of increasing amounts of $\mathrm{RBr}, T=25^{\circ} \mathrm{C}$. (a) $\mathrm{RBr}=\mathrm{EBA}$, scan rate $=0.1 \mathrm{~V} \mathrm{~s}^{-1}$, (b) $\mathrm{RBr}=\mathrm{MBP}$, scan rate $=0.1 \mathrm{~V} \mathrm{~s}^{-1}$, (c) $\mathrm{RBr}=\mathrm{BAN}$, scan rate $=0.2 \mathrm{~V} \mathrm{~s}^{-1}$, (d) $\mathrm{RBr}=\mathrm{BPN}$, scan rate $=0.1 \mathrm{~V} \mathrm{~s}^{-1}$, (e) macroinitiator $=\operatorname{PMA}-\operatorname{Br}\left(M_{\mathrm{n}}=2584\right)$, scan rate $=0.2 \mathrm{~V} \mathrm{~s}^{-1}$.

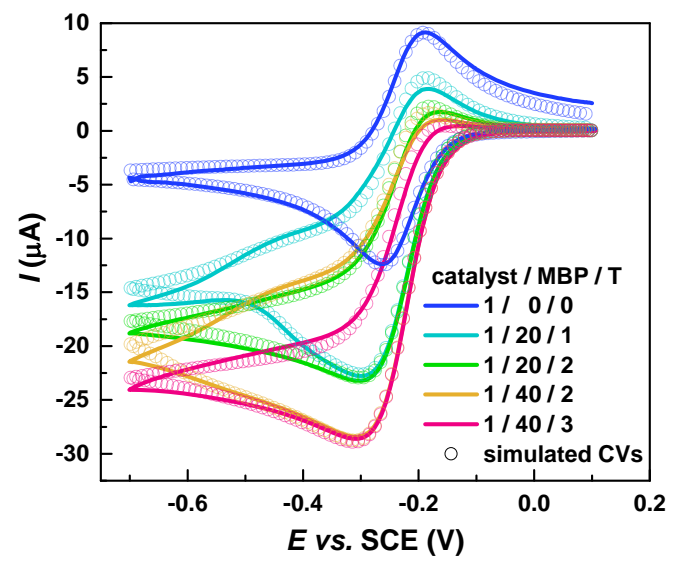

Figure S11. Experimental (lines) and simulated (circles) $\mathrm{CVs}$ for $10^{-3} \mathrm{M} \mathrm{Cu}^{\mathrm{II}} \mathrm{Br}_{2}+1.1 \times 10^{-3} \mathrm{M}$ TPMA in DMF + 0.1 M Et $4 \mathrm{NBF}_{4}$ in the presence of different amounts of MBP and TEMPO (T). Scan rate $=0.1 \mathrm{~V} \mathrm{~s}^{-1}, T=25^{\circ} \mathrm{C}$. The best fit was obtained setting a diffusion limited $k_{\mathrm{d}, \mathrm{OMRP}}==$ $1.3 \times 10^{9} \mathrm{M}^{-1} \mathrm{~s}^{-1}$. 


\section{S5.2. ATRP catalysts}
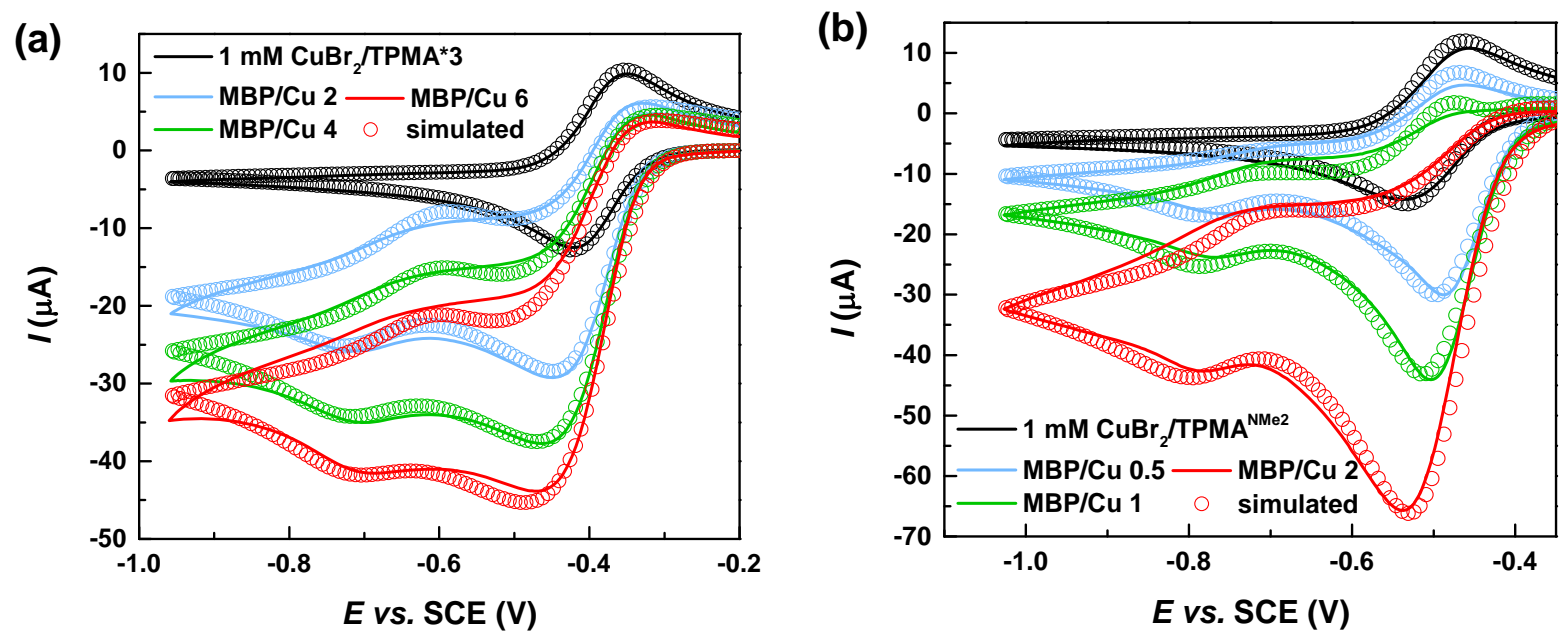

Figure S12. Experimental (lines) and simulated (circles) $\mathrm{CVs}$ for $1 \mathrm{mM} \mathrm{Cu}{ }^{\mathrm{II}} \mathrm{Br}_{2}+1.1 \mathrm{mM}$ (a) $\mathrm{TPMA}^{*} 3$, (b) $\mathrm{TPMA}^{\mathrm{NMe} 2}$ in $\mathrm{DMF}+0.1 \mathrm{M} \mathrm{Et}_{4} \mathrm{NBF}_{4}$, in the absence and presence of increasing amounts of MBP, scan rate $=0.1 \mathrm{~V} \mathrm{~s}^{-1}, T=25^{\circ} \mathrm{C}$. 


\section{S5.3. Solvents}
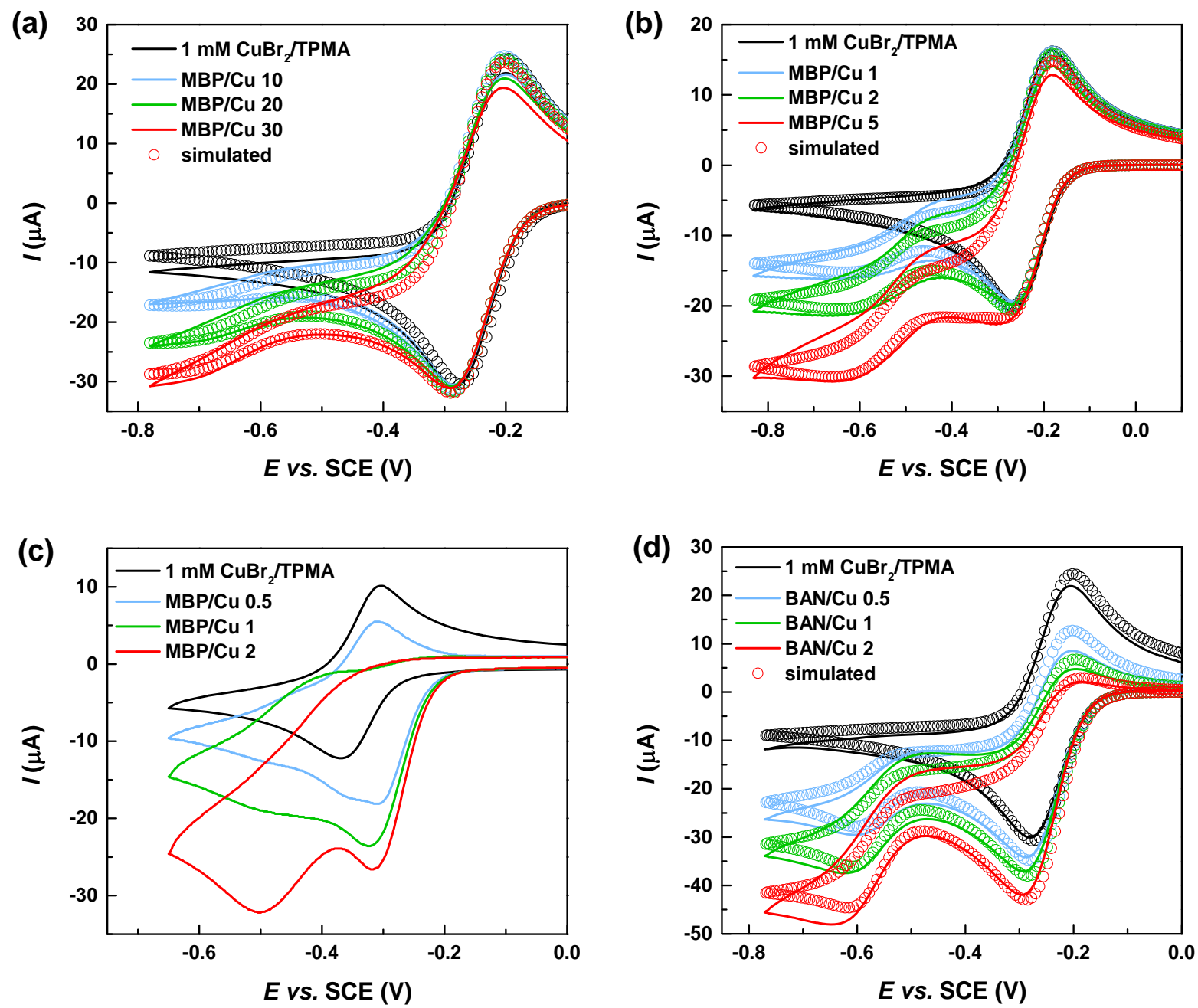

Figure S13. Experimental (lines) and simulated (circles) CVs for $1 \mathrm{mM} \mathrm{Cu}{ }^{\mathrm{II}} \mathrm{Br}_{2}+1.1 \mathrm{mM}$ TPMA in (a,d) $\mathrm{CH}_{3} \mathrm{CN}$, (b) DMSO, (c) $\mathrm{H}_{2} \mathrm{O}+0.1 \mathrm{M} \mathrm{Et}_{4} \mathrm{NBF}_{4}$, in the absence and presence of increasing amounts of (a,b,c) MBP, and (d) BAN, $T=25^{\circ} \mathrm{C}$. Scan rate $=(\mathrm{a}, \mathrm{d}) 0.2 \mathrm{~V} \mathrm{~s}^{-1}$, (b) $0.1 \mathrm{~V} \mathrm{~s}^{-1}$, (c) 0.05 $\mathrm{V} \mathrm{s}^{-1}$. 
Table S6. Values of $k_{\mathrm{a}, \mathrm{OMRP}}$ and standard deviation of the fitting returned for the simulations at fixed $K$ omrp of experimental $\mathrm{CVs}$ of $\mathrm{CuBr}_{2} / \mathrm{TPMA}+\mathrm{BAN}$ in $\mathrm{CH}_{3} \mathrm{CN}$ (Figure S13d).

\begin{tabular}{llll}
\hline KOMRP (M) & $\boldsymbol{k}_{\mathrm{a}, \mathrm{OMRP}}\left(\mathbf{s}^{\mathbf{- 1}}\right)$ & $\boldsymbol{k}_{\mathrm{d}, \text { OMRP }}\left(\mathbf{M}^{-\mathbf{1}} \mathbf{s}^{\mathbf{- 1}}\right)$ & Standard deviation \\
\hline $\mathbf{1 . 1} \times \mathbf{1 0}^{-\mathbf{8}}$ & $5.4 \times 10^{-1}$ & $4.9 \times 10^{7}$ & 0.0557 \\
$\mathbf{1 . 1} \times \mathbf{1 0}^{-\mathbf{9}}$ & $4.6 \times 10^{-2}$ & $4.2 \times 10^{7}$ & 0.0471 \\
$\mathbf{1 . 1} \times \mathbf{1 0}^{-\mathbf{1 0}}$ & $4.6 \times 10^{-3}$ & $4.2 \times 10^{7}$ & 0.0464 \\
$\mathbf{1 . 1} \times \mathbf{1 0}^{-\mathbf{1 1}}$ & $4.8 \times 10^{-4}$ & $4.3 \times 10^{7}$ & 0.0463 \\
\hline
\end{tabular}

Table S7. Parameters obtained through CV simulation without including CRT in the model for the system $\mathrm{Cu} / \mathrm{TPMA}+\mathrm{MBP}$ in DMF at $25^{\circ} \mathrm{C} .^{\text {a }}$

\begin{tabular}{ll}
\hline & $\mathrm{MBP}$ \\
\hline$K_{\text {ATRP }}$ & $(2.8 \pm 0.2) \times 10^{-5}$ \\
$k_{\mathrm{a}, \mathrm{ATRP}}\left(\mathrm{M}^{-1} \mathrm{~s}^{-1}\right)$ & $(3.5 \pm 0.1) \times 10^{3}$ \\
$k_{\mathrm{d}, \mathrm{ATRP}}\left(\mathrm{M}^{-1} \mathrm{~s}^{-1}\right)$ & $(1.2 \pm 0.1) \times 10^{8}$ \\
$K_{\text {OMRP }}(\mathrm{M})$ & $(5.7 \pm 0.3) \times 10^{-7}$ \\
$k_{\mathrm{a}, \mathrm{OMRP}}\left(\mathrm{s}^{-1}\right)$ & $(7.4 \pm 1.5) \times 10^{2}$ \\
$k_{\mathrm{d}, \mathrm{OMRP}}\left(\mathrm{M}^{-1} \mathrm{~s}^{-1}\right)$ & $(1.3 \pm 0.2) \times 10^{9 \mathrm{~b}}$ \\
$k_{\mathrm{dis}, \mathrm{R}}^{\mathrm{I}}\left(\mathrm{s}^{-1}\right)$ & $>10^{2 \mathrm{c}}$ \\
$E_{\mathrm{R}}^{\ominus} v s . \mathrm{SCE}(\mathrm{V})$ & $-0.435 \pm 0.021$ \\
$E_{\mathrm{Br}}^{\ominus}-E_{\mathrm{R}}^{\ominus}(\mathrm{V})$ & 0.203 \\
$k_{\mathrm{R}}^{0}\left(\mathrm{~cm} \mathrm{~s}^{-1}\right)$ & $0.004 \pm 0.005$
\end{tabular}

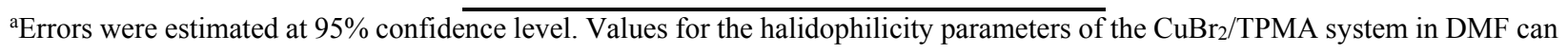
be found in Table 1 in the main text. ${ }^{b}$ Diffusion-limited rate constant calculated via the Smoluchowski equation (see Section S3). ${ }^{\mathrm{c}}$ The CV simulations did not change for values larger than $10^{2} \mathrm{~s}^{-1}$. 


\section{S6. Other Vis-NIR Experiments}
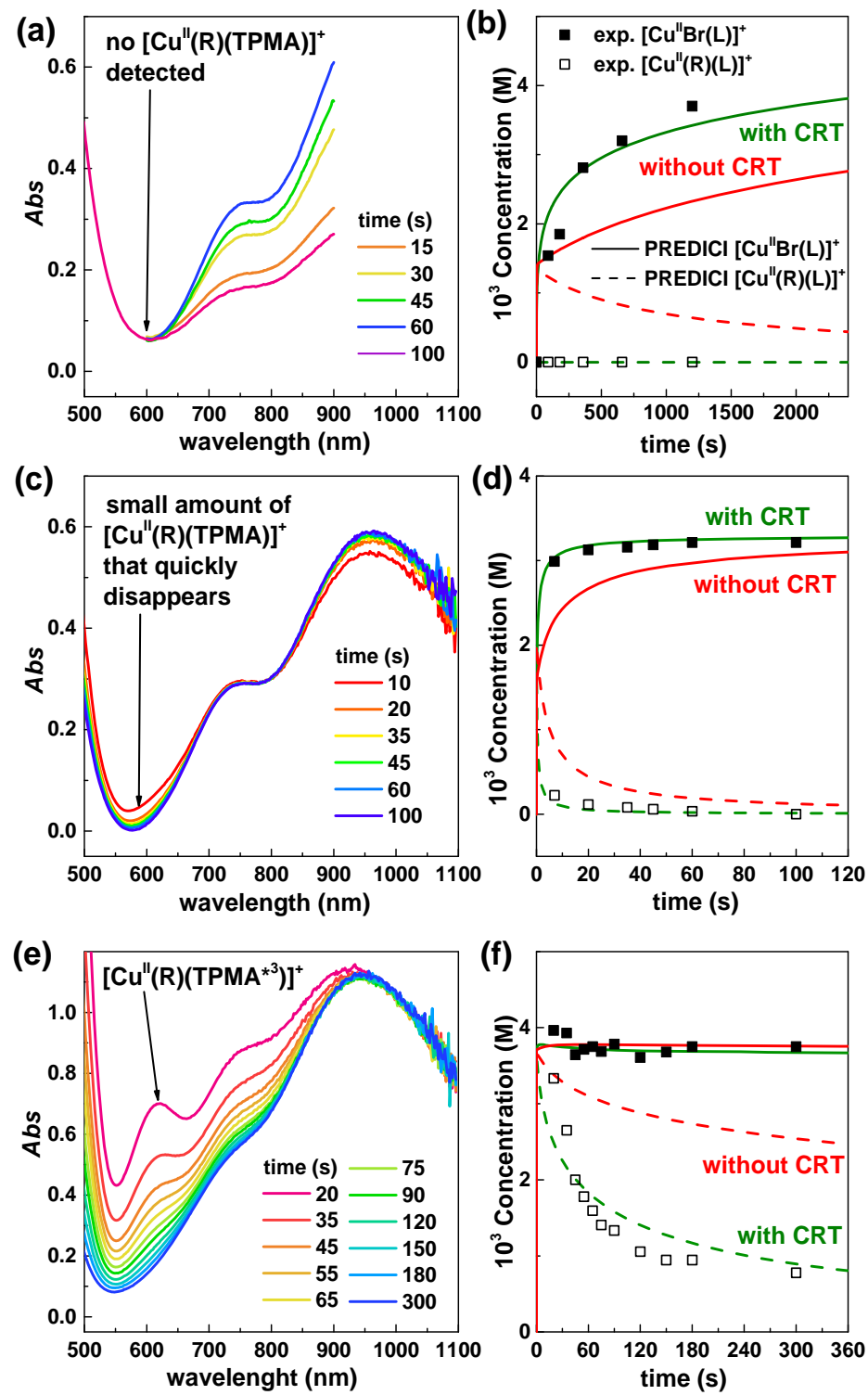

Figure S14. "Termination" experiments between $8 \times 10^{-3} \mathrm{M} \mathrm{Cu}^{\mathrm{II}} \mathrm{Br}_{2} / \mathrm{L}$ and $4 \times 10^{-3} \mathrm{M} \mathrm{MBP}$. (a,b) $\mathrm{L}=$ TPMA, solvent $=\mathrm{CH}_{3} \mathrm{CN}$. (c, d) $\mathrm{L}=$ TPMA, solvent $=$ DMSO. $(\mathrm{e}, \mathrm{f}) \mathrm{L}=$ TPMA $*$, solvent $=$ DMF. Left: Vis-NIR spectra. Right: experimental (squares) and simulated (lines) data for $\left[\mathrm{Cu}^{\mathrm{II}} \mathrm{Br}(\mathrm{L})\right]^{+}$and $\left[\mathrm{Cu}^{\mathrm{II}}(\mathrm{R})(\mathrm{L})\right]^{+}$. The simulations were carried out with the PREDICI software in agreement with the set of equations in Table S8. The concentration of $[\mathrm{Cu}(\mathrm{II})(\mathrm{L})]^{+}$was estimated by using $\varepsilon=162 \mathrm{~L} \cdot \mathrm{mol}^{-1} \cdot \mathrm{cm}^{-1}$ aSt $600 \mathrm{~nm}$ obtained for $\left[\mathrm{Cu}^{\mathrm{II}}\left(\mathrm{CH}_{3} \mathrm{COOEt}\right)(\mathrm{TPMA})\right]^{+}$in Figure S15. 


\section{S7. “Termination” experiment for [Cu$\left.{ }^{\mathrm{I}}(\mathrm{TPMA})\right]^{+}$and EBA in DMF}

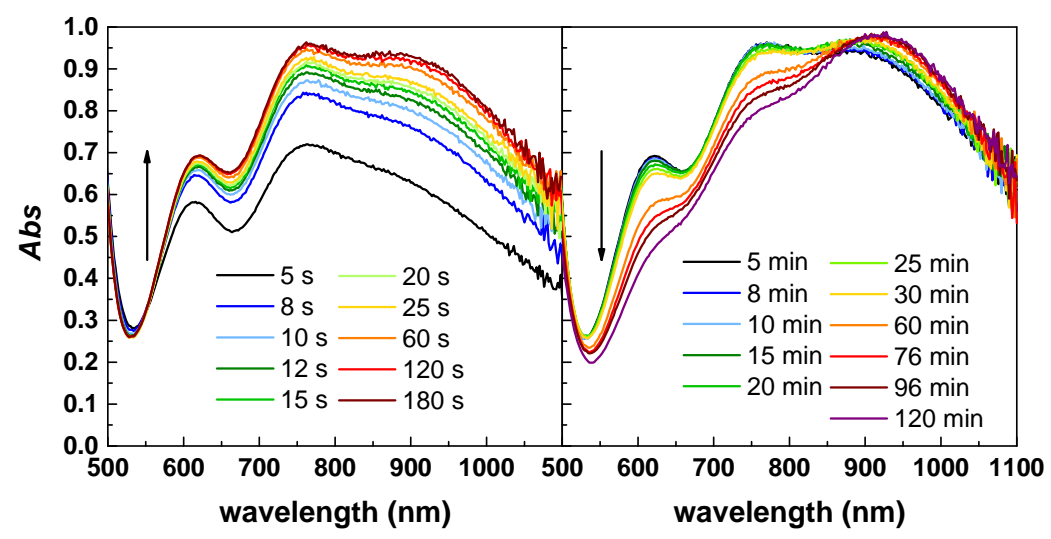

Figure S15. Vis-NIR spectra for the reaction of $8 \mathrm{mM}\left[\mathrm{Cu}^{\mathrm{I}}(\mathrm{TPMA})\right]^{+}$with $4 \mathrm{mM}$ EBA in DMF. By considering the formation of $\left[\mathrm{Cu}^{\mathrm{II}}\left(\mathrm{CH}_{2} \mathrm{COOEt}\right)(\mathrm{TPMA})\right]^{+}$quantitative, $\varepsilon=162 \mathrm{~L} \cdot \mathrm{mol}^{-1} \cdot \mathrm{cm}^{-1}$ at $600 \mathrm{~nm}$ can be calculated for this complex.

\section{S7. PREDICI simulations of “[Cu $\left.{ }^{\mathrm{I}}(\mathrm{L})\right]^{+}:[\mathrm{RBr}] 2$ :1" systems}

Table S8. Model used for PREDICI simulations of "termination" experiments in Figure 6 of the main text and Figure S14 and for the systems in Figure S16-S21.

\begin{tabular}{|c|c|c|}
\hline & Reactions & Parameters \\
\hline & Halidophilicity & \\
\hline 1) & {$\left[\mathrm{Cu}^{\mathrm{I}}(\mathrm{L})\right]^{+}+\mathrm{Br}^{-}=\left[\mathrm{Cu}^{\mathrm{I}} \mathrm{Br}(\mathrm{L})\right]$} & $k_{\mathrm{as}, \mathrm{Br}}^{\mathrm{I}}, k_{\mathrm{dis}, \mathrm{Br}}^{\mathrm{I}}$ \\
\hline \multirow[t]{2}{*}{ 2) } & {$\left[\mathrm{Cu}^{\mathrm{II}}(\mathrm{L})\right]^{2+}+\mathrm{Br}^{-}=\left[\mathrm{Cu}^{\mathrm{II}} \mathrm{Br}(\mathrm{L})\right]^{+}$} & $k_{\mathrm{as}, \mathrm{Br}}^{\mathrm{II}}, k_{\mathrm{dis}, \mathrm{Br}}^{\mathrm{II}}$ \\
\hline & ATRP & \\
\hline \multirow[t]{2}{*}{ 3) } & {$\left[\mathrm{Cu}^{\mathrm{I}}(\mathrm{L})\right]^{+}+\mathrm{RBr}=\left[\mathrm{Cu}^{\mathrm{II}} \mathrm{Br}(\mathrm{L})\right]^{+}+\mathrm{R}^{\bullet}$} & $k_{\mathrm{a}, \mathrm{ATRP}}, k_{\mathrm{d}, \mathrm{ATRP}}$ \\
\hline & $O M R P$ & \\
\hline \multirow[t]{2}{*}{ 4) } & {$\left[\mathrm{Cu}^{\mathrm{I}}(\mathrm{L})\right]^{+}+\mathrm{R}^{\bullet}=\left[\mathrm{Cu}^{\mathrm{II}}(\mathrm{R})(\mathrm{L})\right]^{+}$} & $k_{\mathrm{d}, \mathrm{OMRP}}, k_{\mathrm{a}, \mathrm{OMRP}}$ \\
\hline & Terminations & \\
\hline 5) & $\mathrm{R}^{\bullet}+\mathrm{R}^{\bullet} \rightarrow \mathrm{R}-\mathrm{R}$ & $k_{\mathrm{RT}}$ \\
\hline
\end{tabular}


6) $\quad\left[\mathrm{Cu}^{\mathrm{II}}(\mathrm{R})(\mathrm{L})\right]^{+}+\mathrm{R}^{\bullet} \rightarrow\left[\mathrm{Cu}^{\mathrm{I}}(\mathrm{L})\right]^{+}+$terminated chains $\quad k_{\mathrm{CRT}}$

General conditions: no monomer, $8 \times 10^{-3} \mathrm{M}\left[\mathrm{Cu}^{\mathrm{I}}(\mathrm{L})\right]^{+}, 4 \times 10^{-3} \mathrm{M} \mathrm{RBr}, T=25^{\circ} \mathrm{C}$.

It should be noted that in all Figures below and in Figure 8 in the main text it is reported the evolution of the concentrations of the ATRP activator $\left[\mathrm{Cu}^{\mathrm{I}}(\mathrm{L})\right]^{+}$and the ATRP deactivator $\left[\mathrm{Cu}{ }^{\mathrm{II}} \mathrm{Br}(\mathrm{L})\right]^{+}$. The sum of the concentration of these two species may differ from the total initial concentration of $\mathrm{Cu}$ species, due to the presence of $\left[\mathrm{Cu}^{\mathrm{I}} \mathrm{Br}(\mathrm{L})\right]$, which is not active in ATRP, and to a smaller extent to the presence of the organometallic species.
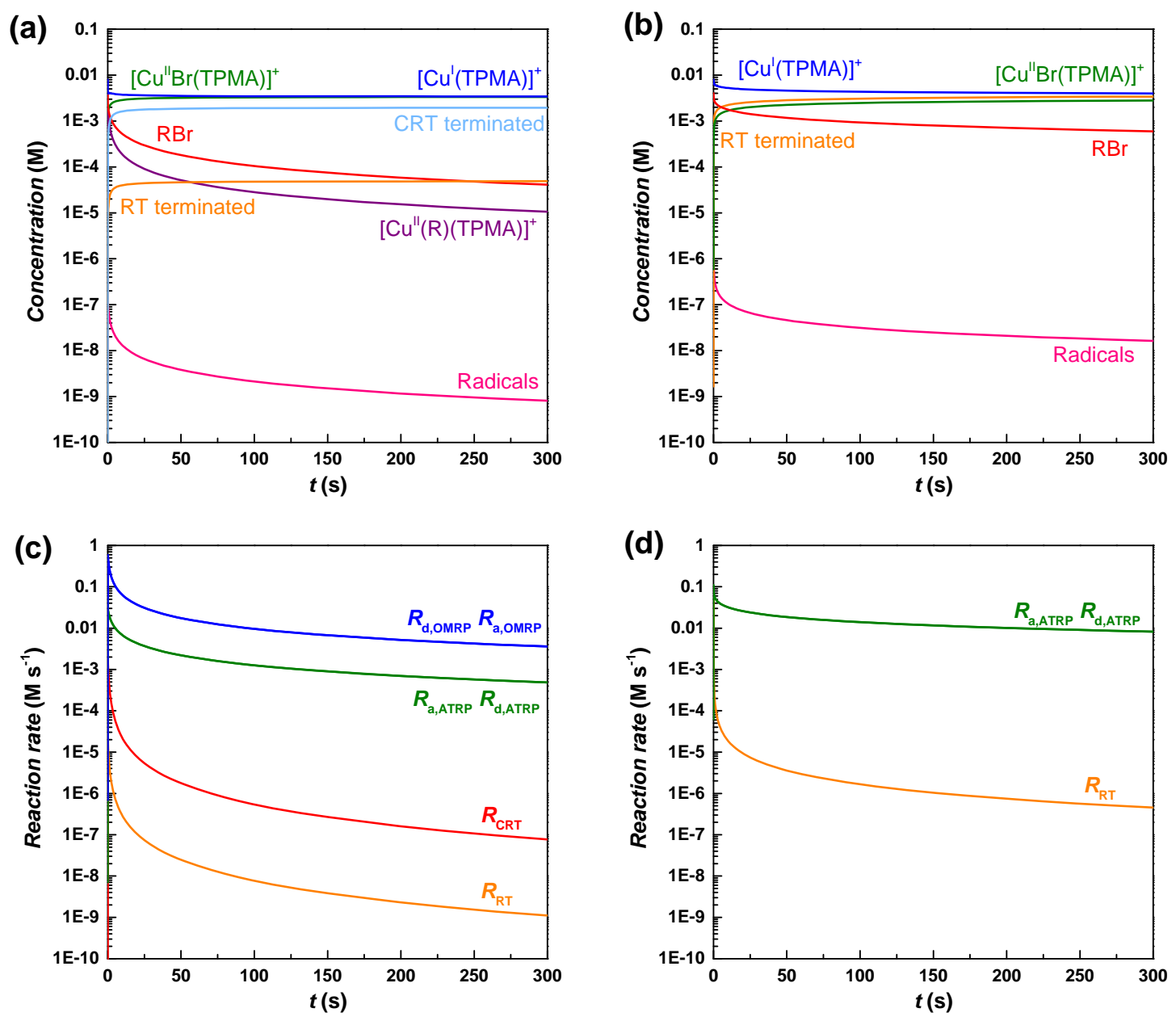

Figure S16. PREDICI simulations for the termination experiment between $\left[\mathrm{Cu}^{\mathrm{I}}(\mathrm{TPMA})\right]^{+}$and MBP in DMF using the parameters obtained from CV simulations. (a,c): considering the OMRP equilibrium, (b,d): discarding the OMRP contribution. 

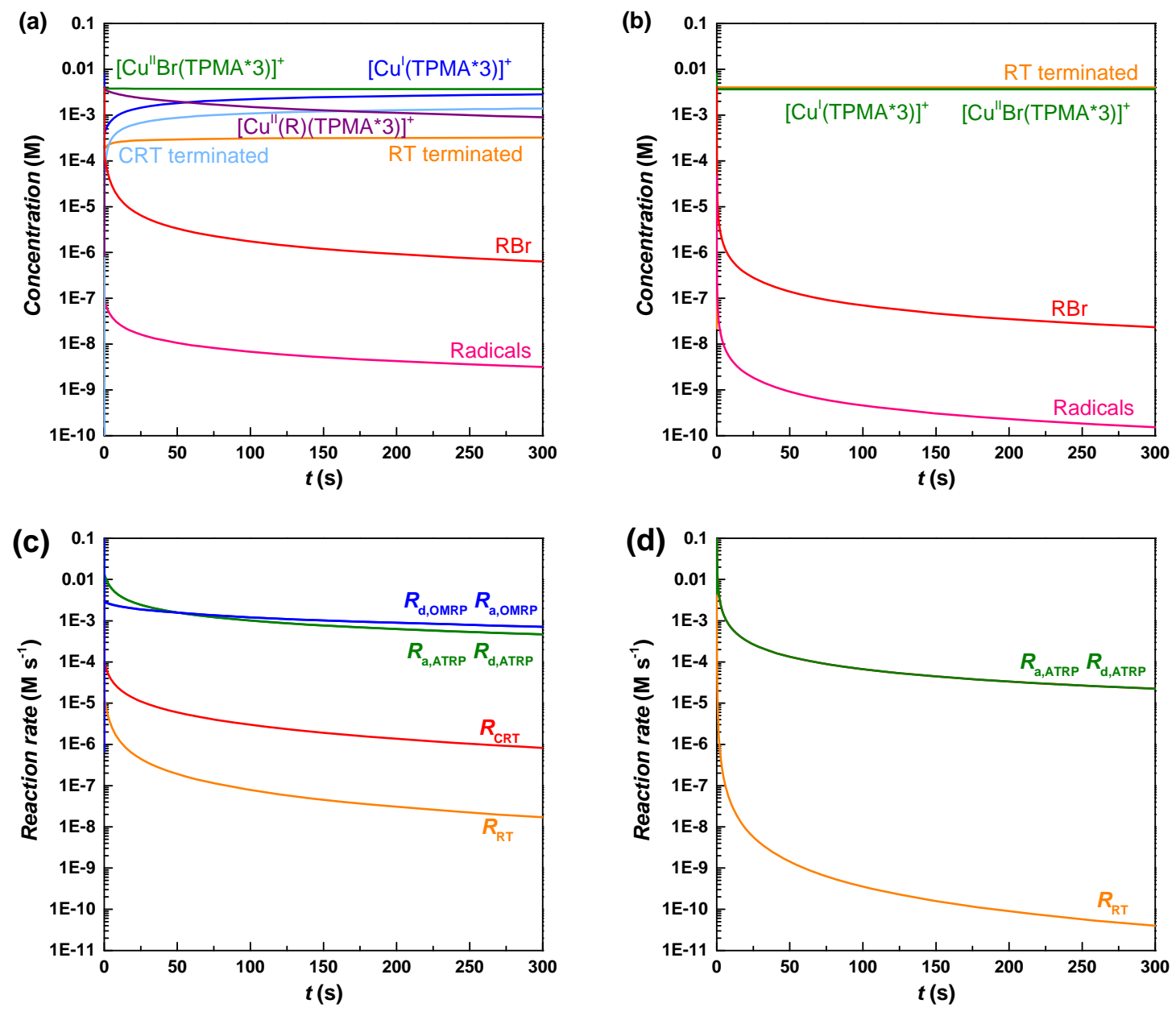

Figure S17. PREDICI simulations for the termination experiment between $\left[\mathrm{Cu}^{\mathrm{I}}\left(\mathrm{TPMA}^{* 3}\right)\right]^{+}$and MBP in DMF using the parameters obtained from CV simulations. (a,c): considering the OMRP equilibrium, (b,d): discarding the OMRP contribution.
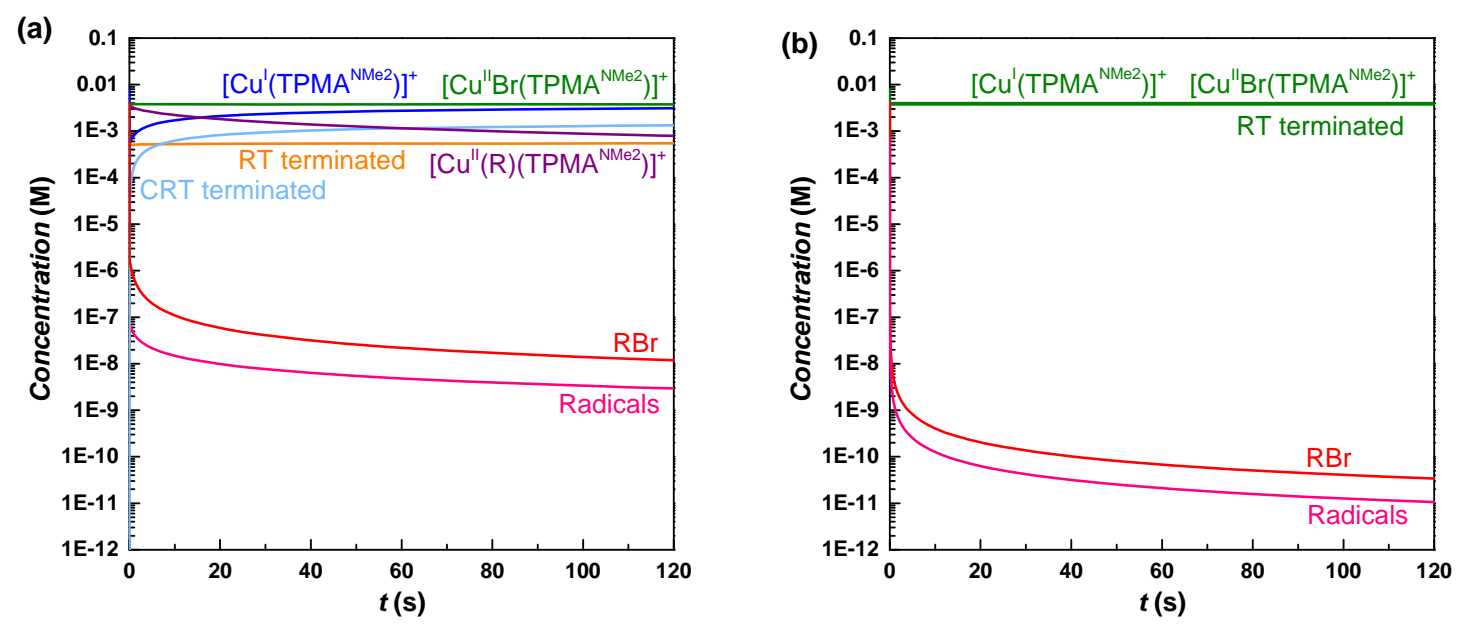

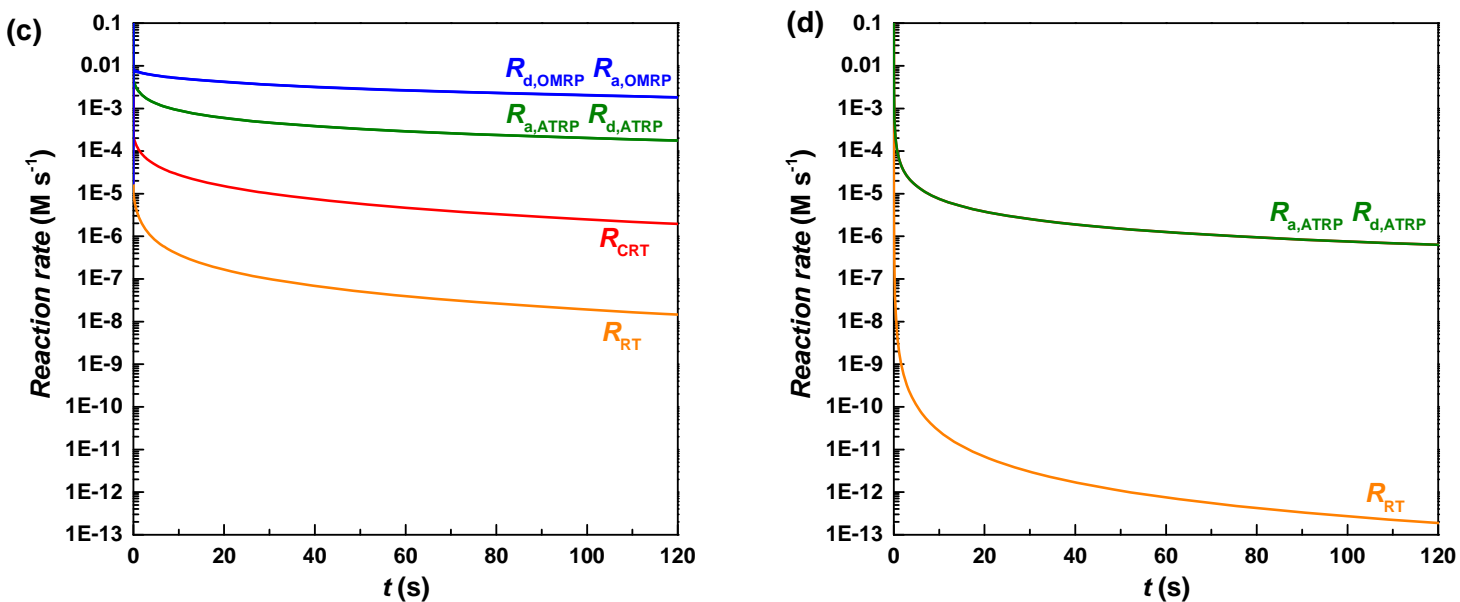

Figure S18. PREDICI simulations for the termination experiment between $\left[\mathrm{Cu}^{\mathrm{I}}\left(\mathrm{TPMA}^{\mathrm{NMe} 2}\right)\right]^{+}$and MBP in DMF using the parameters obtained from CV simulations. (a,c): considering the OMRP equilibrium, (b,d): discarding the OMRP contribution.
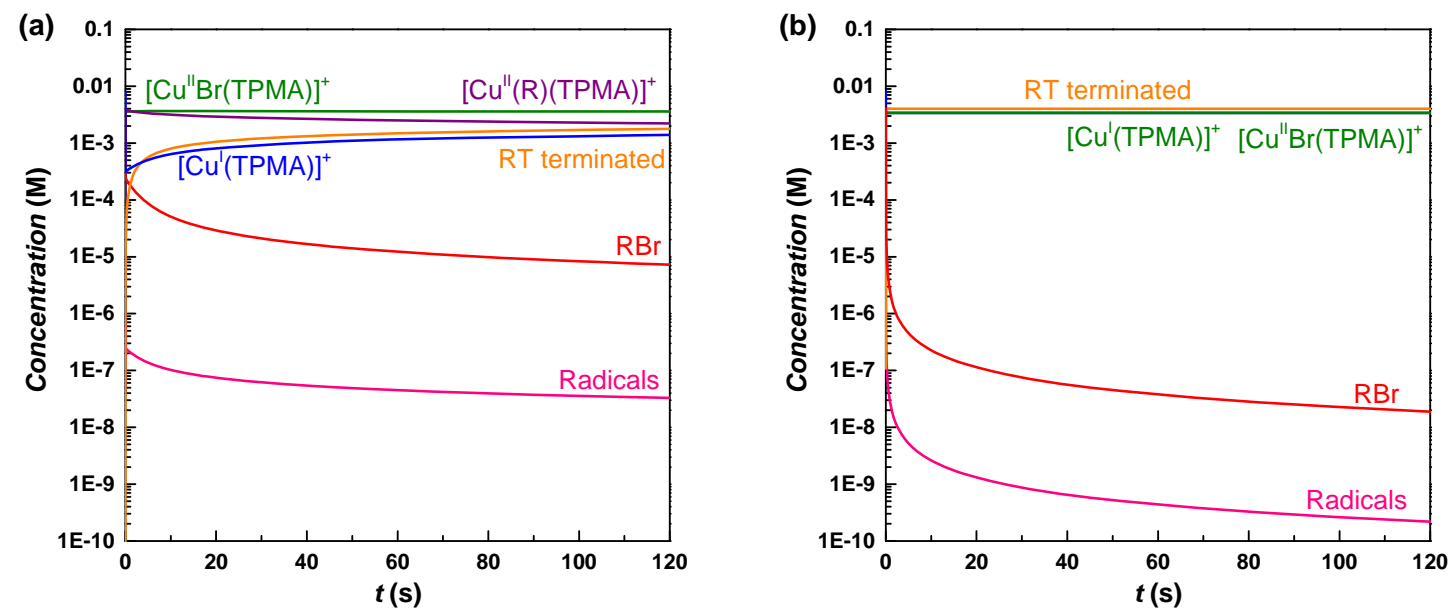

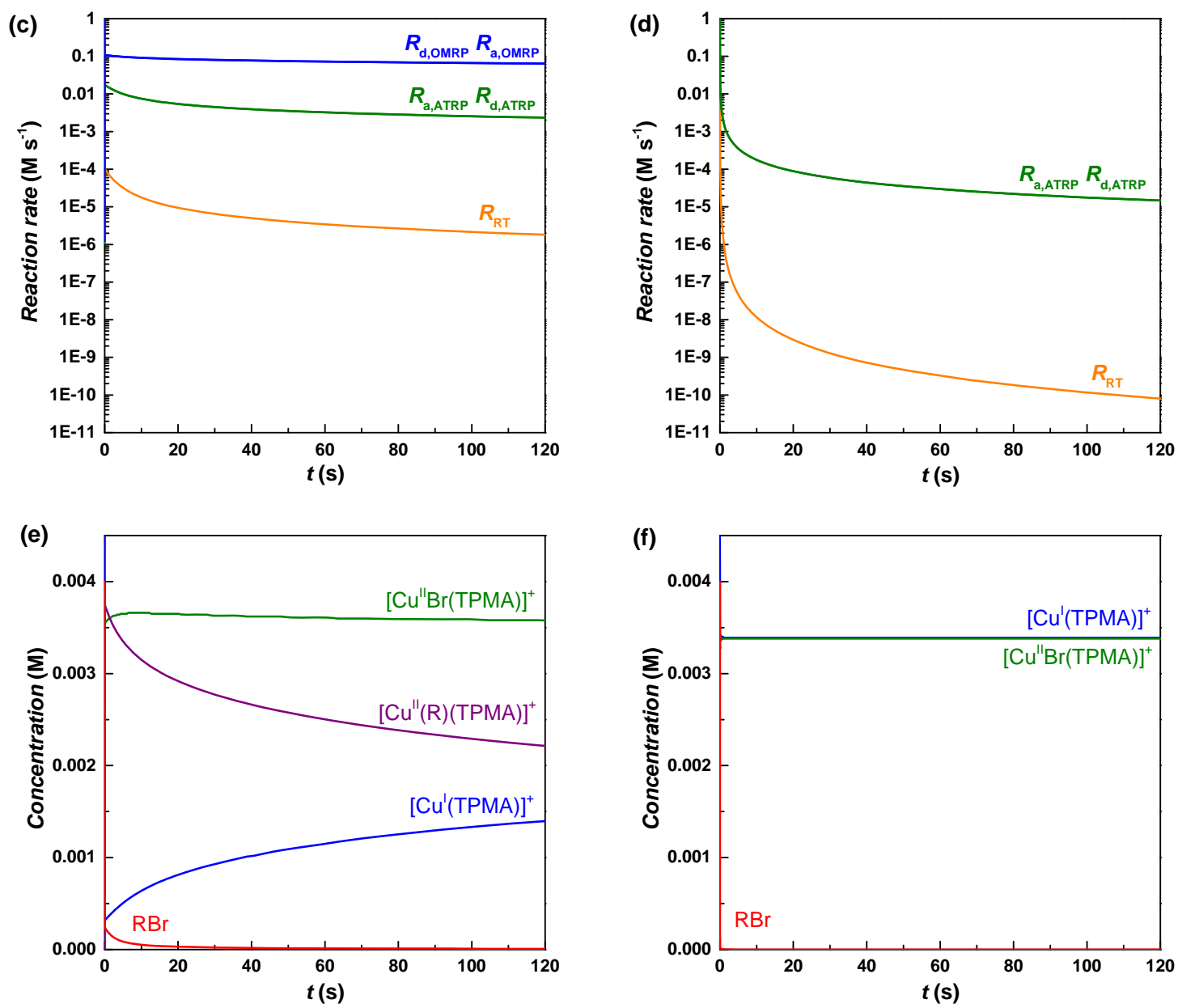

Figure S19. PREDICI simulations for the termination experiment between $\left[\mathrm{Cu}^{\mathrm{I}}(\mathrm{TPMA})\right]^{+}$and BPN in DMF using the parameters obtained from CV simulations. $(\mathrm{a}, \mathrm{c}, \mathrm{e})$ : considering the OMRP equilibrium, (b,d,f): discarding the OMRP contribution.
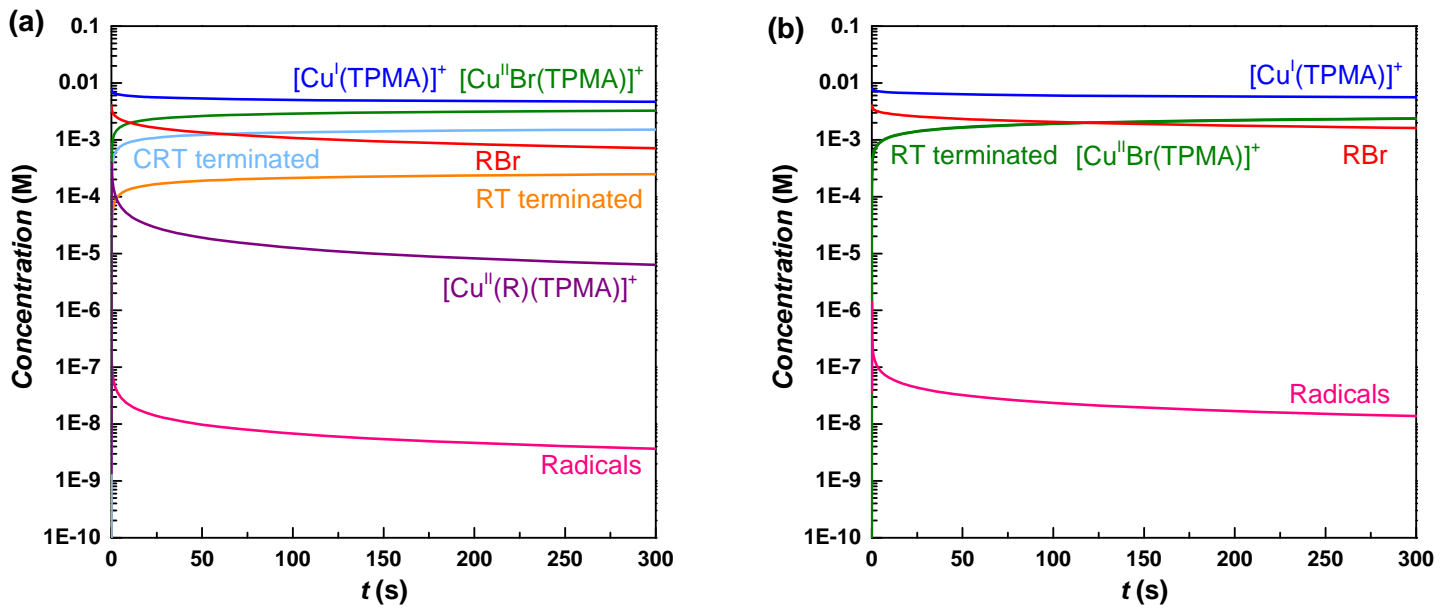

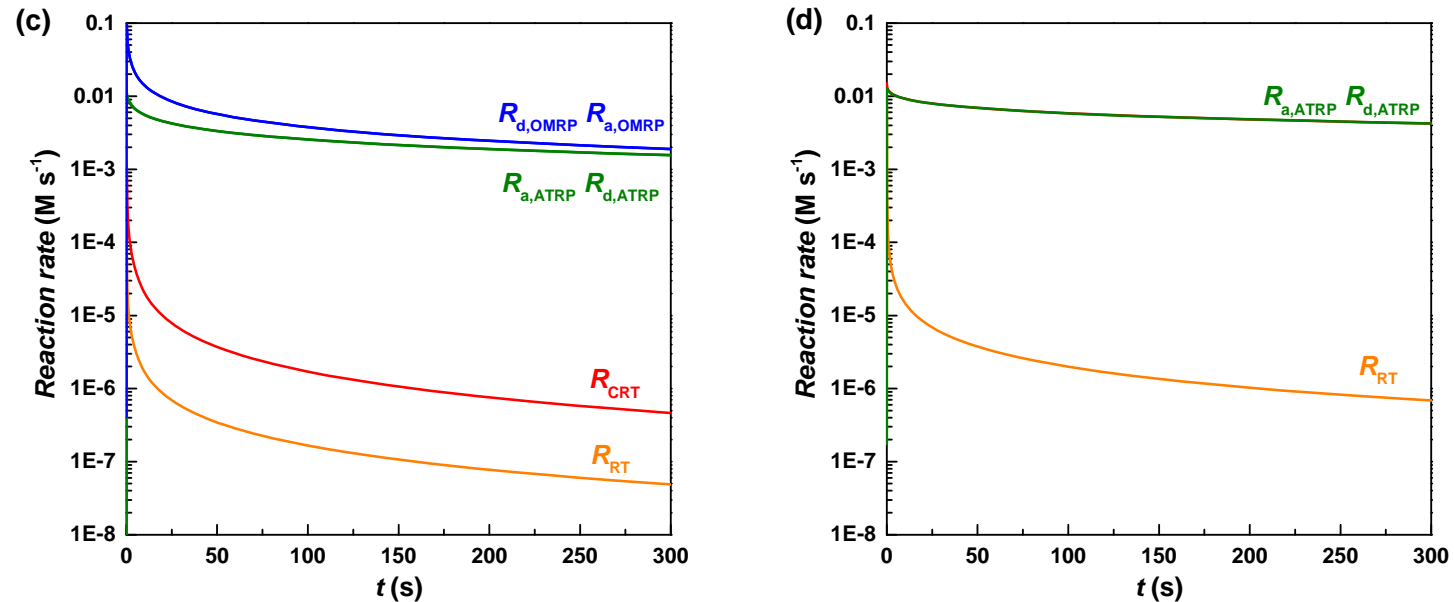

Figure S20. PREDICI simulations for the termination experiment between $\left[\mathrm{Cu}^{\mathrm{I}}(\mathrm{TPMA})\right]^{+}$and $\mathrm{MBP}$ in $\mathrm{CH}_{3} \mathrm{CN}$ using the parameters obtained from $\mathrm{CV}$ simulations. (a,c): considering the OMRP equilibrium, (b,d): discarding the OMRP contribution.
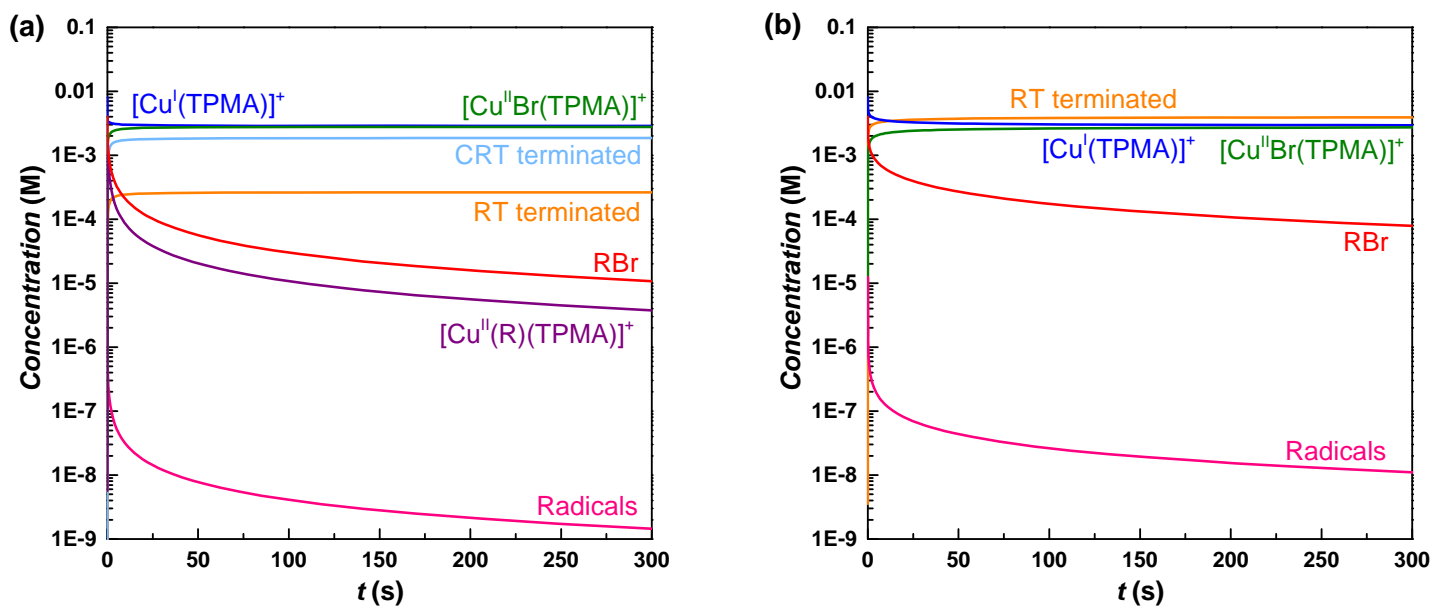

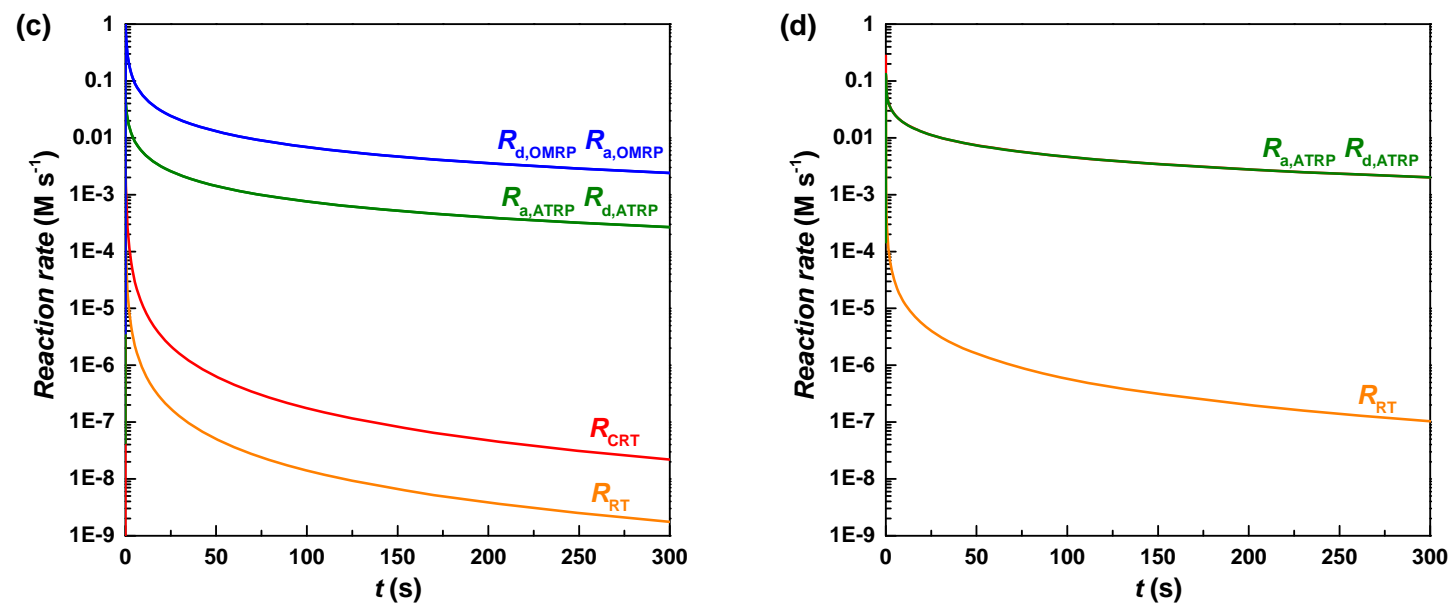

Figure S21. PREDICI simulations for the termination experiment between $\left[\mathrm{Cu}^{\mathrm{I}}(\mathrm{TPMA})\right]^{+}$and MBP in DMSO using the parameters obtained from CV simulations. (a,c): considering the OMRP equilibrium, (b,d): discarding the OMRP contribution.
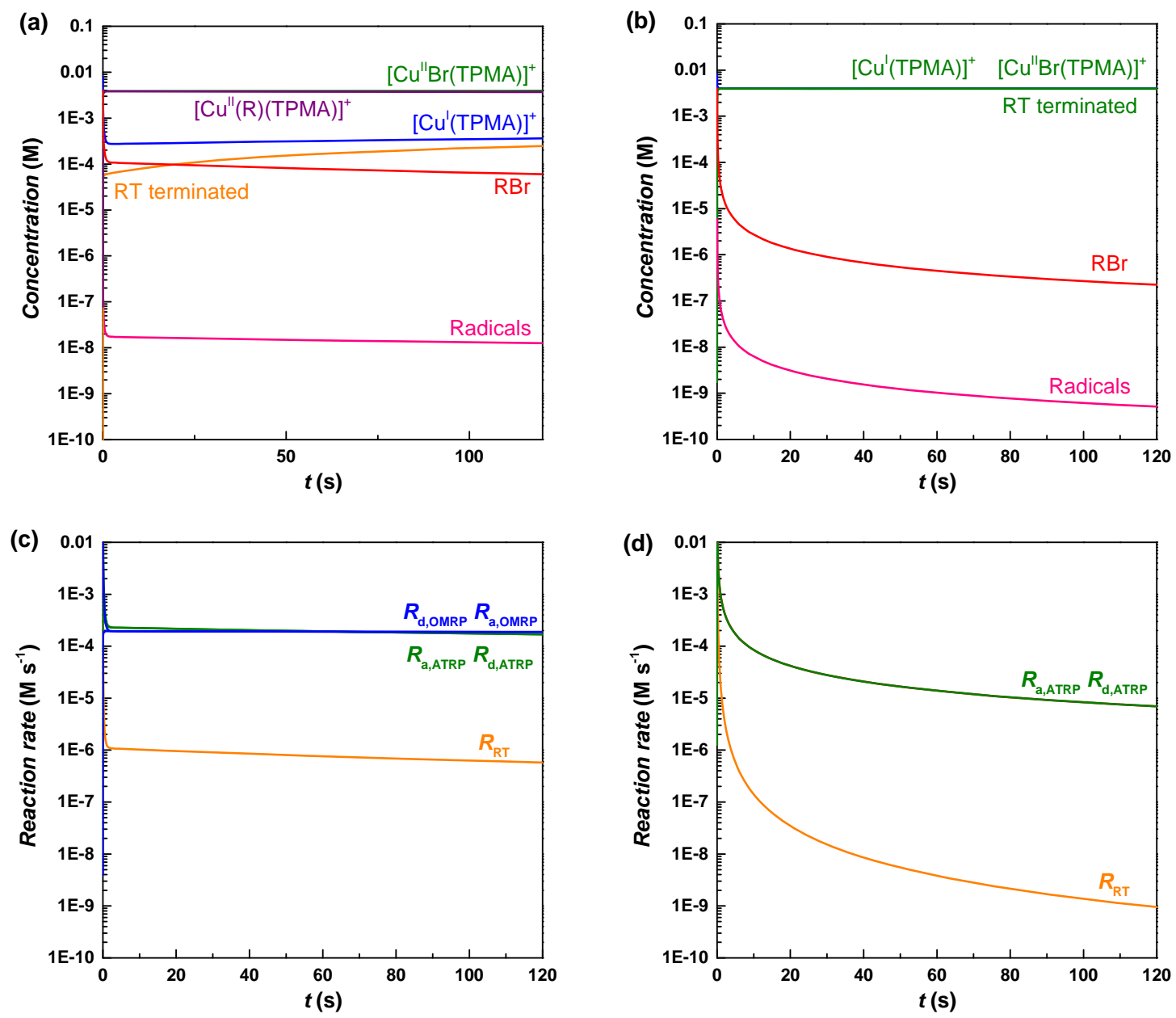

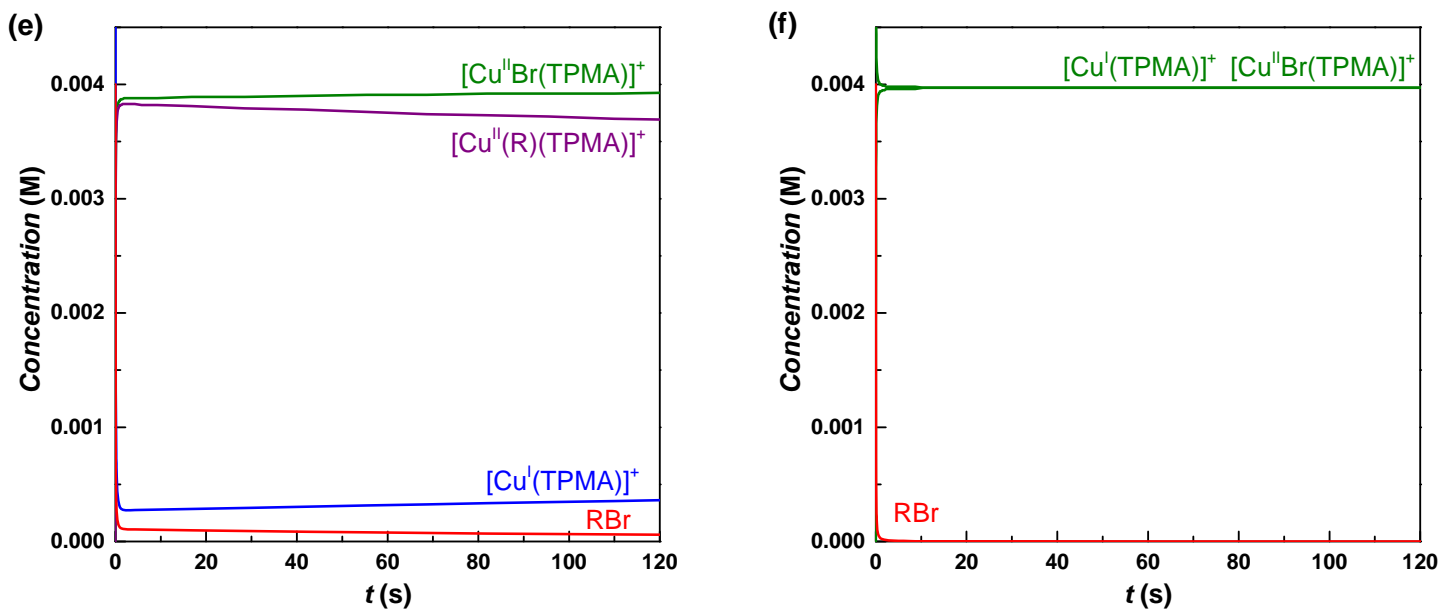

Figure S22. PREDICI simulations for the termination experiment between $\left[\mathrm{Cu}^{\mathrm{I}}(\mathrm{TPMA})\right]^{+}$and BAN in $\mathrm{CH}_{3} \mathrm{CN}$ using the parameters obtained from $\mathrm{CV}$ simulations. (a,c,e): considering the OMRP equilibrium, (b,d,f): discarding the OMRP contribution.

\section{S8. PREDICI simulations under polymerization conditions}

Table S9. Model used for PREDICI simulations under polymerization conditions.

\begin{tabular}{|c|c|c|}
\hline & Reactions & Parameters \\
\hline & Halidophilicity & \\
\hline 1) & {$\left[\mathrm{Cu}^{\mathrm{I}}(\mathrm{L})\right]^{+}+\mathrm{Br}^{-}=\left[\mathrm{Cu}^{\mathrm{I}} \mathrm{Br}(\mathrm{L})\right]$} & $k_{\mathrm{as}, \mathrm{Br}}^{\mathrm{I}}, k_{\mathrm{dis}, \mathrm{Br}}^{\mathrm{I}}$ \\
\hline \multirow[t]{2}{*}{ 2) } & {$\left[\mathrm{Cu}^{\mathrm{II}}(\mathrm{L})\right]^{2+}+\mathrm{Br}^{-}=\left[\mathrm{Cu}^{\mathrm{II}} \mathrm{Br}(\mathrm{L})\right]^{+}$} & $k_{\mathrm{as}, \mathrm{Br}}^{\mathrm{II}}, k_{\mathrm{dis}, \mathrm{Br}}^{\mathrm{II}}$ \\
\hline & Reduction $^{\mathrm{a}}$ & \\
\hline 3) & {$\left[\mathrm{Cu}^{\mathrm{II}} \mathrm{Br}(\mathrm{L})\right]^{+}+\mathrm{Sn}(\mathrm{II})=[\mathrm{Cu} \mathrm{Br}(\mathrm{L})]+\mathrm{Sn}(\mathrm{III})$} & $k_{\text {red(II) }}$ \\
\hline \multirow[t]{2}{*}{ 4) } & {$\left[\mathrm{Cu}^{\mathrm{II}} \mathrm{Br}(\mathrm{L})\right]^{+}+\mathrm{Sn}(\mathrm{III})=\left[\mathrm{Cu}{ }^{\mathrm{I}} \mathrm{Br}(\mathrm{L})\right]+\mathrm{Sn}(\mathrm{IV})$} & $k_{\text {red(III) }}$ \\
\hline & ATRP & \\
\hline 5) & {$\left[\mathrm{Cu}^{\mathrm{I}}(\mathrm{L})\right]^{+}+\mathrm{RBr}=\left[\mathrm{Cu}{ }^{\mathrm{II}} \mathrm{Br}(\mathrm{L})\right]^{+}+\mathrm{R}^{\bullet}$} & $k_{\mathrm{a}, \mathrm{ATRP}}, k_{\mathrm{d}, \mathrm{ATRP}}$ \\
\hline 6) & {$\left[\mathrm{Cu}^{\mathrm{I}}(\mathrm{L})\right]^{+}+\mathrm{P}_{\mathrm{n}} \mathrm{Br}=\left[\mathrm{Cu}{ }^{\mathrm{II}} \mathrm{Br}(\mathrm{L})\right]^{+}+\mathrm{P}_{\mathrm{n}}^{\bullet}$} & $k_{\mathrm{a}, \mathrm{ATRP}}, k_{\mathrm{d}, \mathrm{ATRP}}$ \\
\hline
\end{tabular}


$\begin{array}{lll}\text { 7) } & {\left[\mathrm{Cu}^{\mathrm{I}}(\mathrm{L})\right]^{+}+\mathrm{R}^{\bullet}=\left[\mathrm{Cu}^{\mathrm{II}}(\mathrm{R})(\mathrm{L})\right]^{+}} & k_{\mathrm{d}, \text { OMRP },} k_{\mathrm{a}, \text { OMRP }} \\ \text { 8) } & {\left[\mathrm{Cu}^{\mathrm{I}}(\mathrm{L})\right]^{+}+\mathrm{P}_{\mathrm{n}}^{\bullet}=\left[\mathrm{Cu}^{\mathrm{II}}\left(\mathrm{P}_{\mathrm{n}}\right)(\mathrm{L})\right]^{+}} & k_{\mathrm{d}, \text { OMRP },}, k_{\mathrm{a}, \text { OMRP }}\end{array}$

Initiation and Propagation

9) $\mathrm{R}^{\bullet}+\mathrm{M} \rightarrow \mathrm{P}^{\bullet} \quad k_{\mathrm{p}}$

10) $\mathrm{P}_{\mathrm{n}}^{\bullet}+\mathrm{M} \rightarrow \mathrm{P}_{\mathrm{n}+1}{ }^{\bullet} \quad k_{\mathrm{p}}$

\section{Terminations}

11) $\mathrm{R}^{\bullet}+\mathrm{R}^{\bullet} \rightarrow \mathrm{R}-\mathrm{R} \quad k_{\mathrm{RT}}$

12) $\mathrm{P}_{\mathrm{n}}^{\bullet}+\mathrm{R}^{\bullet} \rightarrow \mathrm{P}_{\mathrm{n}}-\mathrm{R} \quad k_{\mathrm{t}}$

13) $\mathrm{P}_{\mathrm{n}}^{\bullet}+\mathrm{P}_{\mathrm{m}}{ }^{\bullet} \rightarrow \mathrm{P}_{\mathrm{n}}-\mathrm{P}_{\mathrm{m}} \quad k_{t, \text { mix }}{ }^{\mathrm{b}}$

14) $\left[\mathrm{Cu}^{\mathrm{II}}(\mathrm{R})(\mathrm{L})\right]^{+}+\mathrm{R}^{\bullet} \rightarrow\left[\mathrm{Cu}^{\mathrm{I}}(\mathrm{L})\right]^{+}+$terminated chains $\quad k_{\mathrm{CRT}}$

15) $\left[\mathrm{Cu}^{\mathrm{II}}(\mathrm{R})(\mathrm{L})\right]^{+}+\mathrm{P}_{\mathrm{n}}^{\bullet} \rightarrow\left[\mathrm{Cu}^{\mathrm{I}}(\mathrm{L})\right]^{+}+$terminated chains $\quad k_{\mathrm{CRT}}$

16) $\left[\mathrm{Cu}^{\mathrm{II}}\left(\mathrm{P}_{\mathrm{n}}\right)(\mathrm{L})\right]^{+}+\mathrm{R}^{\bullet} \rightarrow\left[\mathrm{Cu}^{\mathrm{I}}(\mathrm{L})\right]^{+}+$terminated chains $\quad k$ CRT

17) $\left[\mathrm{Cu}^{\mathrm{II}}\left(\mathrm{P}_{\mathrm{n}}\right)(\mathrm{L})\right]^{+}+\mathrm{P}_{\mathrm{n}}^{\bullet} \rightarrow \mathrm{Cu}^{\mathrm{I}} \mathrm{L}^{+}\left[\mathrm{Cu}^{\mathrm{I}}(\mathrm{L})\right]^{+}+$terminated chains $k_{\mathrm{CRT}}$

${ }^{\mathrm{a}}$ These equations were not relevant for normal ATRP. ${ }^{\mathrm{b}} k_{\mathrm{t}, \mathrm{mix}}=\left(k_{\mathrm{RT}}+k_{\mathrm{t}}\right) / 2$.

Table S10. Rate constants of radical propagation and conventional radical termination at $T=25$ ${ }^{\circ} \mathrm{C}$ used in PREDICI simulations.

\begin{tabular}{lllll}
\hline Monomer & $k_{\mathrm{p}}\left(\mathrm{M}^{-1} \mathrm{~s}^{-1}\right)$ & Ref. & $k_{\mathrm{t}}\left(\mathrm{M}^{-1} \mathrm{~s}^{-1}\right)$ & Ref. \\
\hline Methyl acrylate (MA) & $1.56 \times 10^{4}$ & 19 & $2.45 \times 10^{8}$ & 20 \\
Acrylonitrile (AN) & $3.65 \times 10^{3}$ & 21 & $2.45 \times 10^{8 a}$ & - \\
Methyl methacrylate (MMA) & $3.22 \times 10^{2}$ & 22 & $3.0 \times 10^{7}$ & 23 \\
Styrene (STY) & $8.55 \times 10^{1}$ & 22 & $3.7 \times 10^{7}$ & 24 \\
\hline
\end{tabular}

$\bar{a}$ No $k_{\mathrm{t}}$ for acrylonitrile could be found in the literature, thus we used the same value reported for methyl acrylate.

The reduction rate constants for $\mathrm{Cu}^{\mathrm{II}} \mathrm{Br} 2 / \mathrm{L}$ by $\mathrm{Sn}(\mathrm{II})$ and $\mathrm{Sn}(\mathrm{III})$ were 0.136 and $0.458 \mathrm{M}^{-1} \mathrm{~s}^{-1}$, respectively. ${ }^{25}$ 

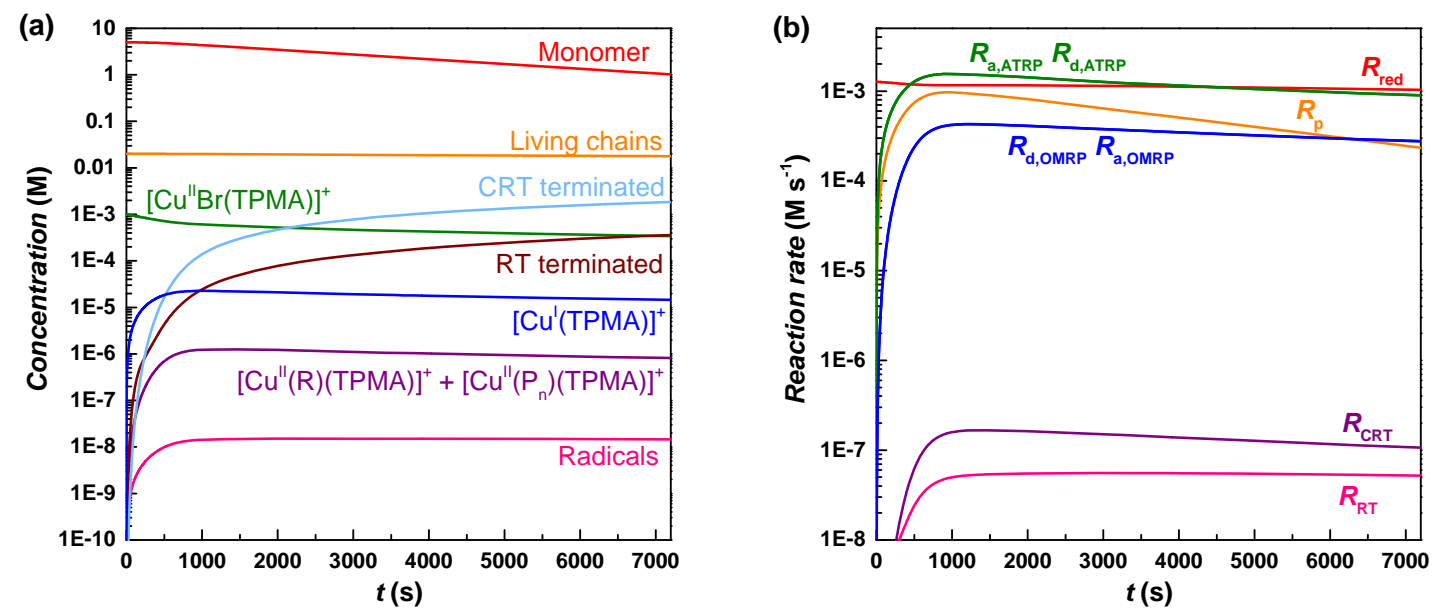

Figure S23. PREDICI simulation of ARGET ATRP of MA in DMF. Conditions: [MA] $=5 \mathrm{M}$ in

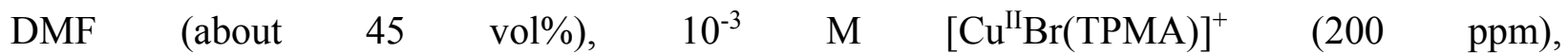
[MA]:[MBP]:[Sn(II)]:[Cu $\left.{ }^{\mathrm{II}} \mathrm{Br}_{2} / \mathrm{TPMA}\right]=250: 1: 0.25: 0.05 .79 \%$ conversion in $2 \mathrm{~h}$, final $\oslash=1.04$.
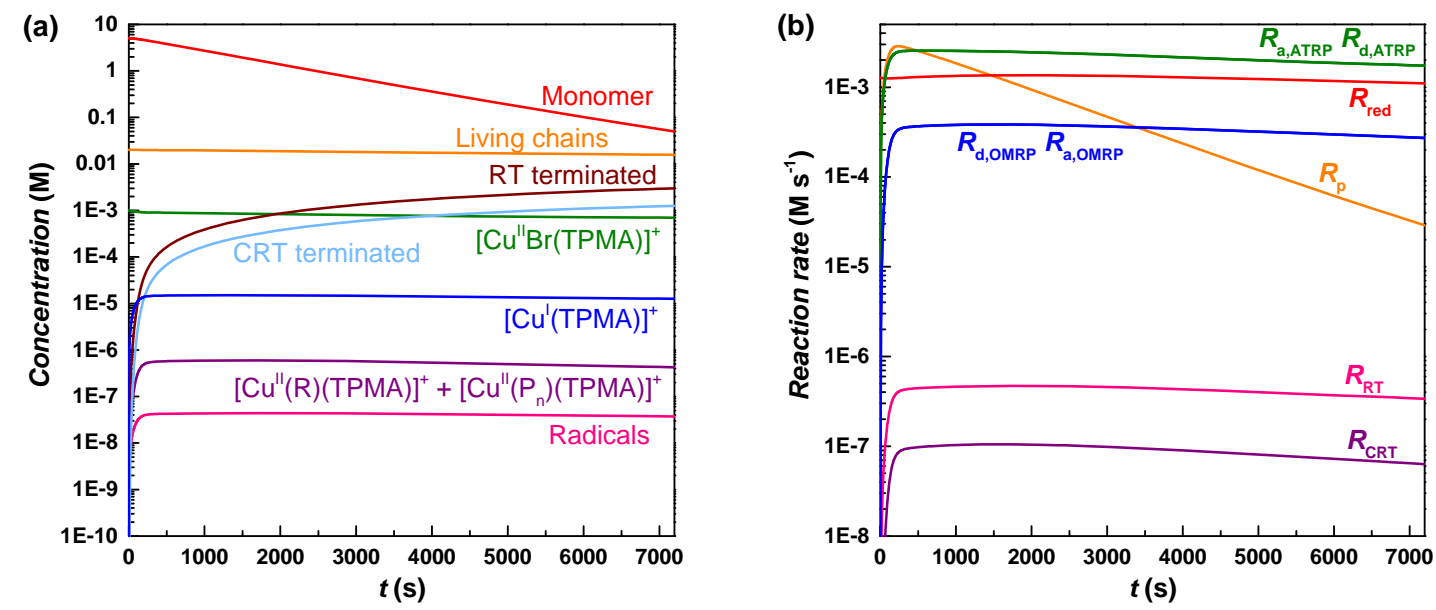

Figure S24. PREDICI simulation of ARGET ATRP of MA in DMSO. Conditions: [MA] $=5 \mathrm{M}$ in DMF, $10^{-3} \mathrm{M}$ [Cu $\left.{ }^{\mathrm{II}} \mathrm{Br}(\mathrm{TPMA})\right]^{+}(200 \mathrm{ppm}),[\mathrm{MA}]:[\mathrm{MBP}]:[\mathrm{Sn}(\mathrm{II})]:\left[\mathrm{Cu}^{\mathrm{II}} \mathrm{Br}_{2} / \mathrm{TPMA}\right]=$ 250:1:0.25:0.05. 99\% conversion in $2 \mathrm{~h}$, final $Ð=1.06$. 

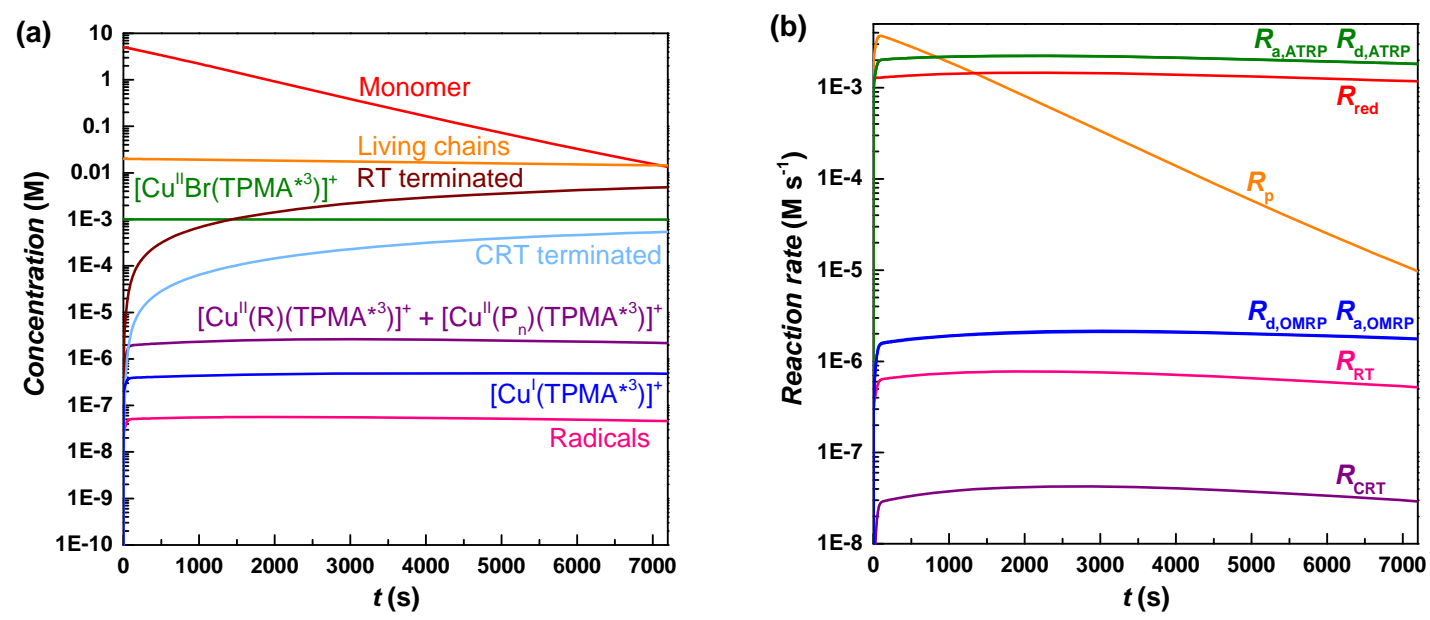

Figure S25. PREDICI simulation of ARGET ATRP of MA in DMF. Conditions: [MA] $=5 \mathrm{M}$ in DMF, $10^{-3} \mathrm{M}\left[\mathrm{Cu}^{\mathrm{II}} \mathrm{Br}(\mathrm{TPMA} * 3)\right]^{+}(200 \mathrm{ppm}),[\mathrm{MA}]:[\mathrm{MBP}]:[\mathrm{Sn}(\mathrm{II})]:\left[\mathrm{Cu}^{\mathrm{II}} \mathrm{Br}_{2} / \mathrm{TPMA}^{*} 3\right]=$ 250:1:0.25:0.05. $>99 \%$ conversion in $2 \mathrm{~h}$, final $\oslash=1.08$.
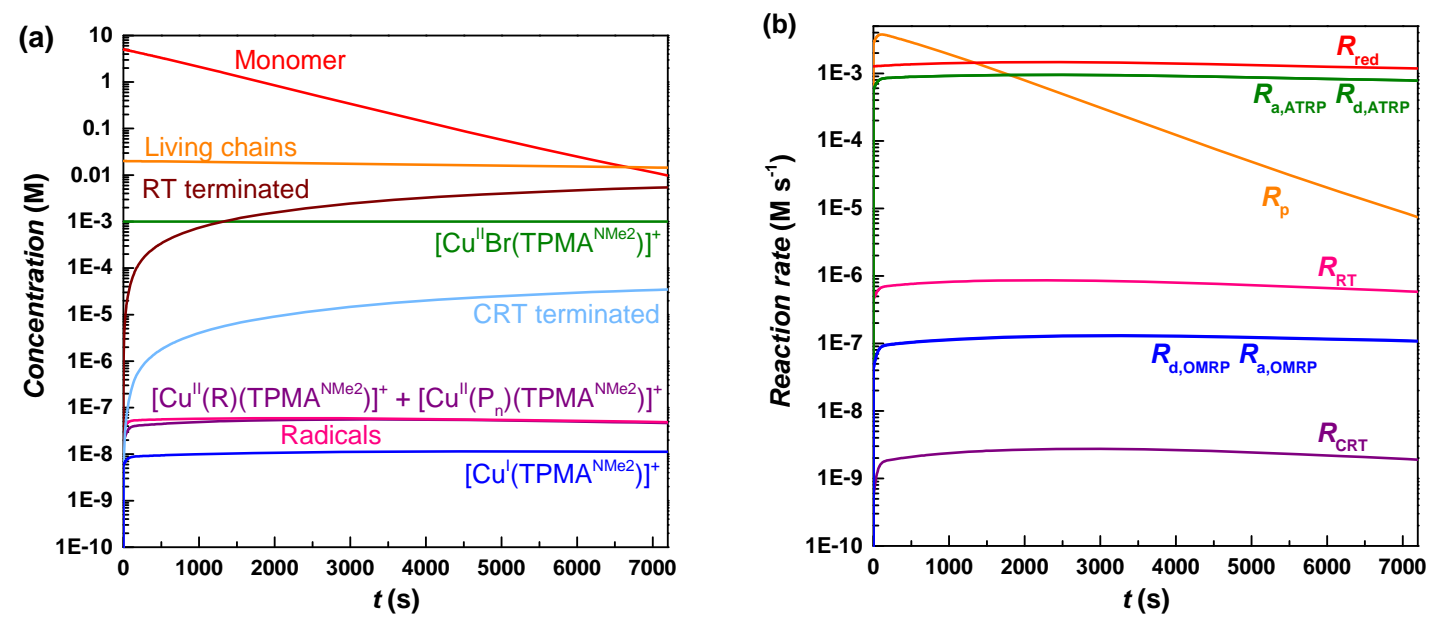

Figure S26. PREDICI simulation of ARGET ATRP of MA in DMF. Conditions: [MA] $=5 \mathrm{M}$ in DMF, $10^{-3} \mathrm{M}\left[\mathrm{Cu}^{\mathrm{II}} \mathrm{Br}\left(\mathrm{TPMA}^{\mathrm{NMe}}\right)\right]^{+}(200 \mathrm{ppm})$, [MA]:[MBP]:[Sn(II)]:[Cu $\left.{ }^{\mathrm{II}} \mathrm{Br}_{2} / \mathrm{TPMA}^{\mathrm{NMe} 2}\right]=$ 250:1:0.25:0.05. $>99 \%$ conversion in $2 \mathrm{~h}$, final $D=1.10$. 

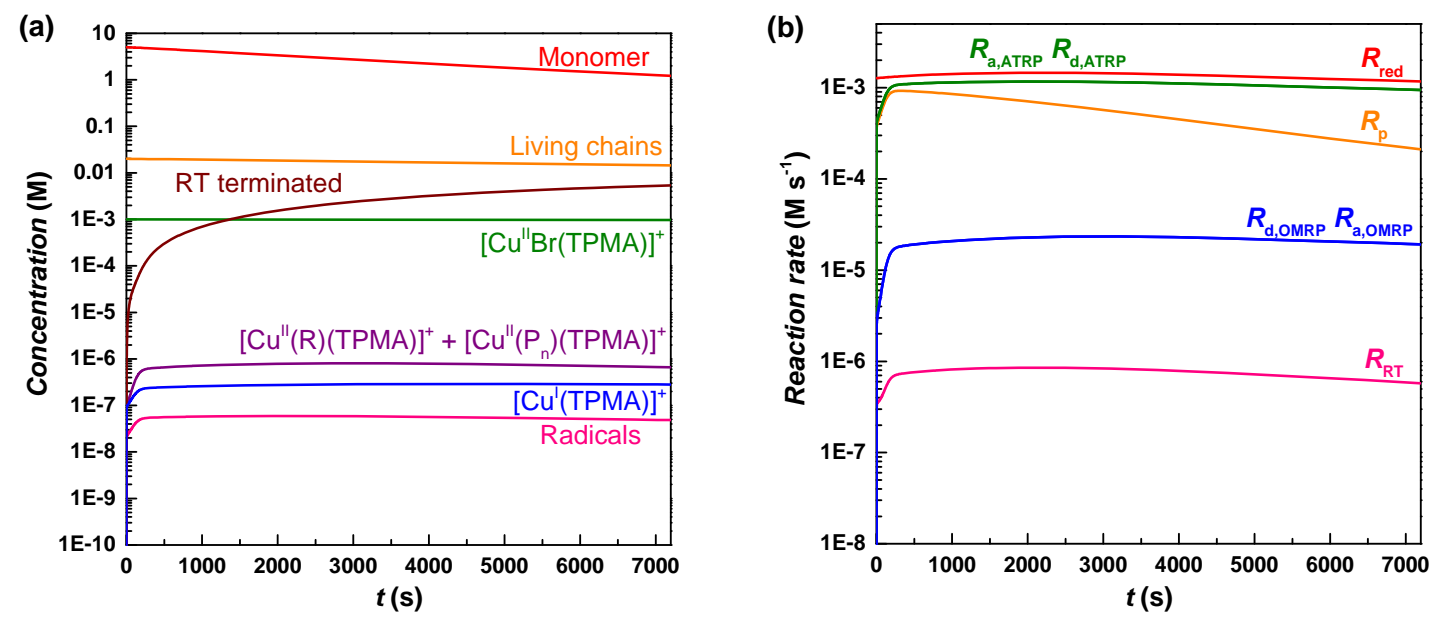

Figure S27. PREDICI simulation of ARGET ATRP of AN in DMF. Conditions: [AN] $=5 \mathrm{M}$ in

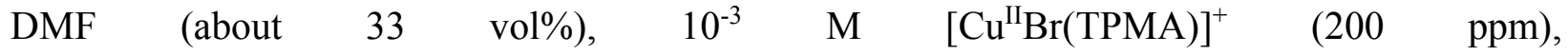
[MA]:[BPN]:[Sn(II)]:[Cu $\left.{ }^{\mathrm{II}} \mathrm{Br} 2 / \mathrm{TPMA}\right]=250: 1: 0.25: 0.05 .84 \%$ conversion in $2 \mathrm{~h}$, final $\oslash=1.06$.
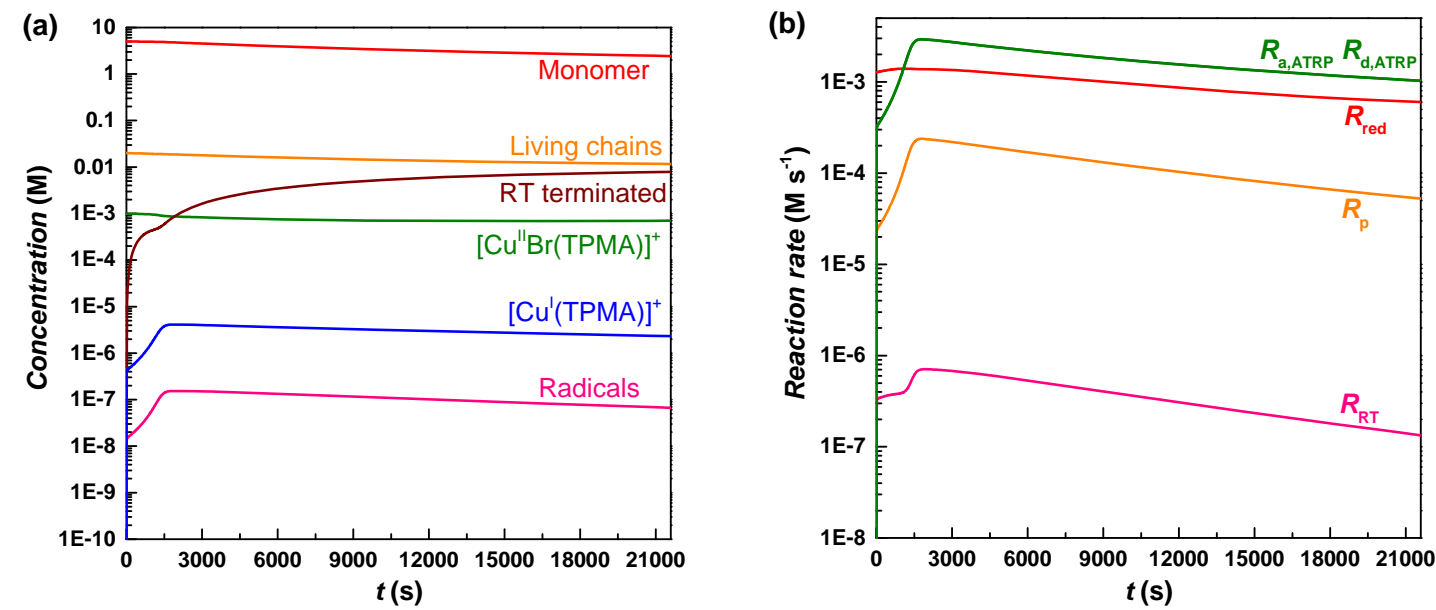

Figure S28. PREDICI simulation of ARGET ATRP of MMA in DMF. Conditions: [MMA] $=5$ $\mathrm{M}$ in $\mathrm{DMF}$ (about $53 \mathrm{vol} \%), \quad 10^{-3} \mathrm{M} \quad\left[\mathrm{Cu}^{\mathrm{II}} \mathrm{Br}(\mathrm{TPMA})\right]^{+} \quad(200 \mathrm{ppm})$, [MA]:[EBiB]:[Sn(II)]:[Cu $\left.{ }^{\mathrm{II}} \mathrm{Br} / \mathrm{TPMA}\right]=250: 1: 0.25: 0.05 .51 \%$ conversion in $6 \mathrm{~h}$, final $\doteq=1.10$ (MW lower than theoretical values). 

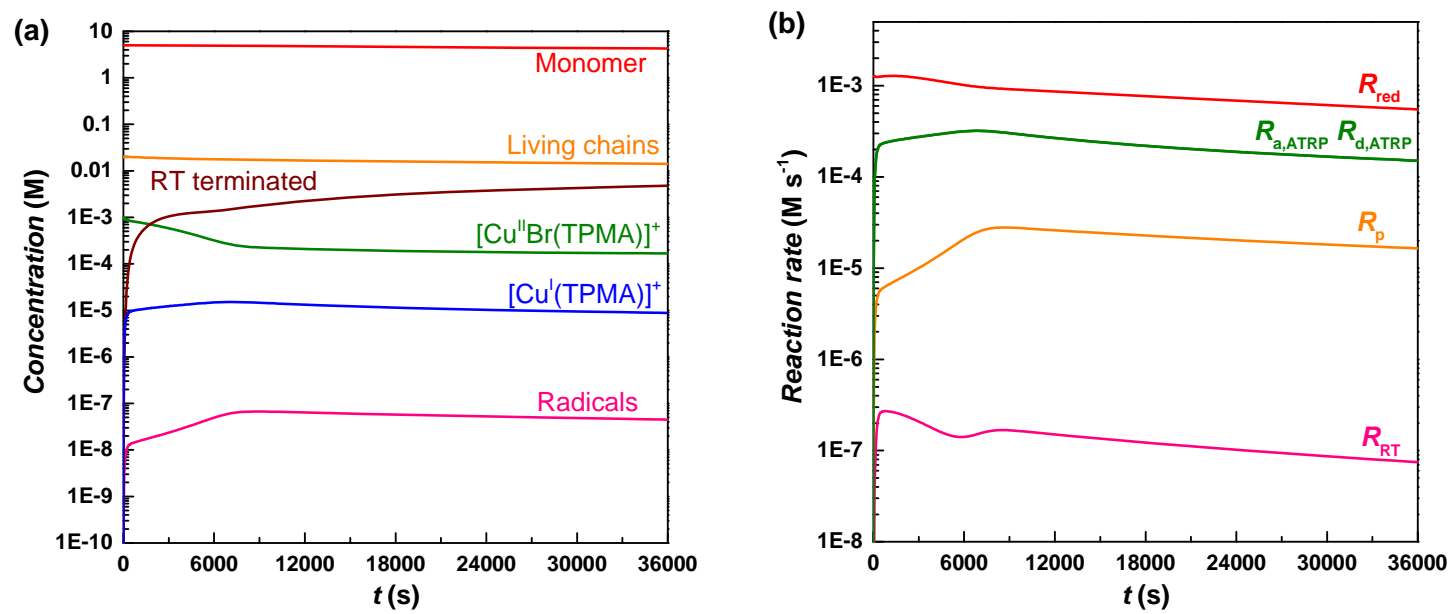

Figure S29. PREDICI simulation of ARGET ATRP of STYA in DMF. Conditions: [STY] $=5 \mathrm{M}$

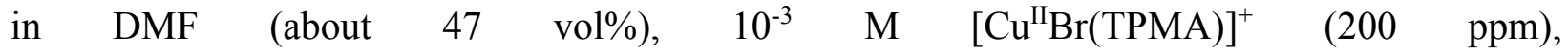
$[\mathrm{MA}]:[\mathrm{PEB}]:[\mathrm{Sn}(\mathrm{II})]:\left[\mathrm{Cu}^{\mathrm{II}} \mathrm{Br}_{2} / \mathrm{TPMA}\right]=250: 1: 0.25: 0.05 .14 \%$ conversion in $10 \mathrm{~h}$, final $Ð=1.09$ (MW lower than theoretical values).
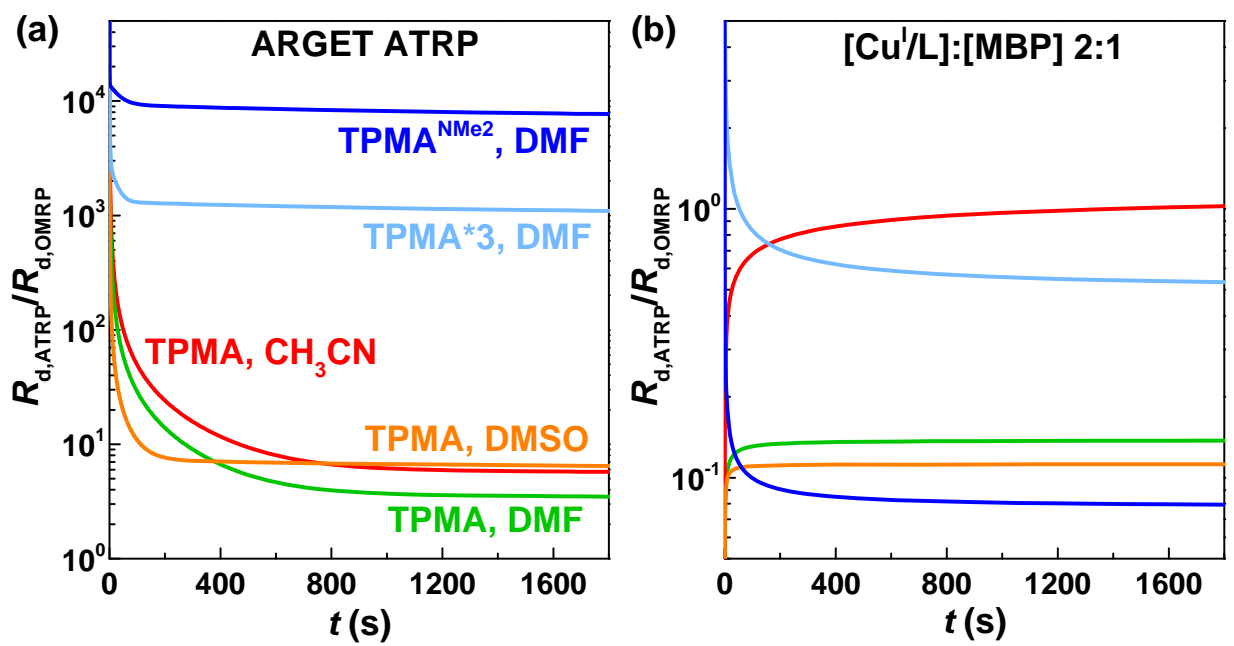

Figure S30. Ratio between the rates of ATRP and OMRP deactivation in (a) ARGET ATRP of MA ([MA] $\left.=5 \mathrm{M} ;[\mathrm{MA}]:[\mathrm{MBP}]:\left[\mathrm{Cu}^{\mathrm{II}} \mathrm{Br} / \mathrm{L}\right]:[\mathrm{Sn}(\mathrm{II})]=250: 1: 0.05: 0.25\right)$, and (b) reaction between $8 \times 10^{-3} \mathrm{M} \mathrm{Cu}^{\mathrm{I} O T f} / \mathrm{L}$ and $4 \times 10^{-3} \mathrm{M} \mathrm{MBP}$, with different catalysts and in different solvents, determined by PREDICI simulation. 


\section{References}

(1) Gahler, A. R. Colorimetric Determination of Copper with Neo-Cuproine. Analytical Chemistry 1954, 26, 577-579.

(2) Falciola, L.; Gennaro, A.; Isse, A. A.; Mussini, P. R.; Rossi, M. The solvent effect in the electrocatalytic reduction of organic bromides on silver. Journal of Electroanalytical Chemistry 2006, 593, 47-56.

(3) Ribelli, T. G.; Augustine, K. F.; Fantin, M.; Krys, P.; Poli, R.; Matyjaszewski, K. Disproportionation or Combination? The Termination of Acrylate Radicals in ATRP. Macromolecules 2017, 50, 7920-7929.

(4) Zerk, T. J.; Bernhardt, P. V. Organo-Copper(II) Complexes as Products of Radical Atom Transfer. Inorganic Chemistry 2017, 56, 5784-5792.

(5) Fantin, M.; Isse, A. A.; Bortolamei, N.; Matyjaszewski, K.; Gennaro, A. Electrochemical approaches to the determination of rate constants for the activation step in atom transfer radical polymerization. Electrochimica Acta 2016, 222, 393-401.

(6) Fantin, M.; Isse, A. A.; Matyjaszewski, K.; Gennaro, A. ATRP in Water: Kinetic Analysis of Active and Super-Active Catalysts for Enhanced Polymerization Control. Macromolecules 2017, 50, 2696-2705.

(7) Valencia, D. P.; González, F. J. Estimation of diffusion coefficients by using a linear correlation between the diffusion coefficient and molecular weight. Journal of Electroanalytical Chemistry 2012, 681, 121-126.

(8) Fantin, M.; Isse, A. A.; Gennaro, A.; Matyjaszewski, K. Understanding the Fundamentals of Aqueous ATRP and Defining Conditions for Better Control. Macromolecules 2015, 48, 68626875.

(9) Lorandi, F.; Fantin, M.; Isse, A. A.; Gennaro, A.; Matyjaszewski, K. New protocol to determine the equilibrium constant of atom transfer radical polymerization. Electrochimica Acta 2018, 260, 648-655.

(10) Trevisanello, E.; De Bon, F.; Daniel, G.; Lorandi, F.; Durante, C.; Isse, A. A.; Gennaro, A. Electrochemically mediated atom transfer radical polymerization of acrylonitrile and poly(acrylonitrile-b-butyl acrylate) copolymer as a precursor for N-doped mesoporous carbons. Electrochimica Acta 2018, 285, 344-354.

(11) Braunecker, W. A.; Tsarevsky, N. V.; Gennaro, A.; Matyjaszewski, K. Thermodynamic components of the atom transfer radical polymerization equilibrium: quantifying solvent effects. Macromolecules 2009, 42, 6348-6360.

(12) Kaur, A.; Ribelli, T. G.; Schröder, K.; Matyjaszewski, K.; Pintauer, T. Properties and ATRP Activity of Copper Complexes with Substituted Tris(2-pyridylmethyl)amine-Based Ligands. Inorganic Chemistry 2015, 54, 1474-1486.

(13) Bard, A. J.; Faulkner, L. R. Electrochemical methods: fundamentals and applications. Wiley New York: 1980; Vol. 2.

(14) Bortolamei, N.; Isse, A. A.; Di Marco, V. B.; Gennaro, A.; Matyjaszewski, K. Thermodynamic Properties of Copper Complexes Used as Catalysts in Atom Transfer Radical Polymerization. Macromolecules 2010, 43, 9257-9267. 
(15) Fantin, M.; Isse, A. A.; Venzo, A.; Gennaro, A.; Matyjaszewski, K. Atom Transfer Radical Polymerization of Methacrylic Acid: A Won Challenge. Journal of the American Chemical Society 2016, 138, 7216-7219.

(16) Isse, A. A.; Bortolamei, N.; De Paoli, P.; Gennaro, A. On the mechanism of activation of copper-catalyzed atom transfer radical polymerization. Electrochimica Acta 2013, 110, 655-662.

(17) Schuh, H. H.; Fischer, H. The kinetics of the bimolecular sel reaction of $t$ butyl radicals in solution. I. Termination rates. Helvetica Chimica Acta 1978, 61, 2130-2164.

(18) NIST Standard Reference Database Number 69, June 2005 Release, http://webbook.nist.gov/chemistry/.

(19) Buback, M.; Kurz, C. H.; Schmaltz, C. Pressure dependence of propagation rate coefficients in free radical homopolymerizations of methyl acrylate and dodecyl acrylate. Macromolecular Chemistry and Physics 1998, 199, 1721-1727.

(20) Buback, M.; Kuelpmann, A.; Kurz, C. Termination Kinetics of Methyl Acrylate and Dodecyl Acrylate Free Radical Homopolymerizations up to High Pressure. Macromolecular Chemistry and Physics 2002, 203, 1065-1070.

(21) Junkers, T.; Koo, S. P.; Barner-Kowollik, C. Determination of the propagation rate coefficient of acrylonitrile. Polymer Chemistry 2010, 1, 438-441.

(22) Mahabadi, H. K.; O'driscoll, K. Absolute rate constants in free-radical polymerization. III. Determination of propagation and termination rate constants for styrene and methyl methacrylate. Journal of Macromolecular Science-Chemistry 1977, 11, 967-976.

(23) Barth, J.; Buback, M. SP-PLP-EPR Investigations into the Chain Length Dependent Termination of Methyl Methacrylate Bulk Polymerization. Macromolecular rapid communications 2009, 30, 1805-1811.

(24) Buback, M.; Gilbert, R. G.; Hutchinson, R. A.; Klumperman, B.; Kuchta, F. D.; Manders, B. G.; O'Driscoll, K. F.; Russell, G. T.; Schweer, J. Critically evaluated rate coefficients for free radical polymerization, 1. Propagation rate coefficient for styrene. Macromolecular Chemistry and Physics 1995, 196, 3267-3280.

(25) Payne, K. A.; D’hooge, D. R.; Van Steenberge, P. H. M.; Reyniers, M.-F.; Cunningham, M. F.; Hutchinson, R. A.; Marin, G. B. ARGET ATRP of Butyl Methacrylate: Utilizing Kinetic Modeling To Understand Experimental Trends. Macromolecules 2013, 46, 3828-3840.

(26) De Paoli, P.; Isse, A. A.; Bortolamei, N.; Gennaro, A. New insights into the mechanism of activation of atom transfer radical polymerization by $\mathrm{Cu}(\mathrm{i})$ complexes. Chem. Commun. 2011, 47, 3580-3582.

(27) Zerk, T. J.; Bernhardt, P. V. Redox-coupled structural changes in copper chemistry: Implications for atom transfer catalysis. Coord. Chem. Rev. 2018, 375, 173-190. 